\title{
Účesy jako „uměni“‘? Nástin vlasových úprav a jejich symboliky v Africe
}

\author{
Martin Rychlík \\ Katedra kulturologie Filozofické fakulty Univerzity Karlovy v Praze, Celetná 20, 11000 Praha 1 \\ Do redakce doručeno 15. ledna 2013; k publikaci přijato 5. dubna 2013
}

\begin{abstract}
COIFFURES AS A FORM OF „ART“? OUTLINE OF HAIRSTYLES AND THEIR SYMBOLISM IN AFRICAN CULTURE
ABSTRACT Hair - whether present or absent, long or short, bound or unbound, colored or natural - marks a person and its role in society. It defines a person's gender, sexual availability and desirability, age or social status. Especially in African culture and art is significance of coiffures enormous, as is shown in ethnographic and historical evidence in this brief outline. The great significance of hair in Black Africa has been clear through the centuries.
\end{abstract}

KEY WORDS Coiffures; Africa; Hairstyles; Combing; Hairdressing; Symbols; Art; Culture

ABSTRAKT Vlasy - at již rostlé nebo chybějící, dlouhé či krátké, svázané či nespoutané, barvené nebo přirozené - definují jedince a jeho roli ve společnosti. Odkazují k jeho pohlaví, sexuální dostupnosti, věku nebo sociálnímu statusu. Zvláště v africké kultuře a umění je důležitost účesů enormní, jak je ukázáno na etnografických i historických dokladech v tomto stručném nástinu. Velký význam vlasů v subsaharské Africe je zjevný napříč staletími.

KLÍČOVÁ SLOVA účesy; Afrika; vlasy; česání; symbolika; kadeřnictví; umění; kultura

\section{ÚVOD A METODOLOGIE}

Úprava vlasů či vousů a péče o ně je lidem natolik vlastní, že už i v „archiválním“ soupisu 67 kulturních univerzálií je antropolog George P. Murdock zařadil mezi jevy, jež jsou společné všem lidským komunitám v čase a prostoru (Murdock 1945). O důvodech, proč lidé oproti svým předkům ztratili tolik chlupů na těle, ale na hlavě si je mocně ponechali, stále uvažují fyzičtí antropologové (Rantala 2007, Morris 1971 aj.). Antropologové sociální a kulturní se zase mohou věnovat přečetným významům vlasů v lidské společnosti, nicméně na to, o jak závažné téma jde, není ucelených studií o symbolice vlasů mnoho (Rychlík 2013b, Banek 2010, Rejchrtová 2008, Tiedemann 2007, Corson 2005, Sieber \& Herreman 2000, Hiltebeitel \& Miller 1998, Synnott 1987, Cooper 1971, Hallpike 1969, Leach 1958).

V připravované knižní monografii (Rychlík 2013a) jsem se pokusil na základě historicko-antropologické analýzy vysle- dovat několik nejdůležitějších funkcí, jež vlasy a účesy v lidské kultuře měly, mají - a patrně ještě nějaký čas i mít budou. Jedná se o čtyři hlavní kategorie, které se mohou v různých bodech překrývat a doplňovat: funkce magicko-náboženská, funkce rituálně-přestupní, funkce sociálně-skupinová a funkce dekorativně-erotická (více Rychlík 2013a, 2013b), přičemž posledně jmenovaná je $\mathrm{v}$ Africe obzvláště zřetelná a vizuálně reprezentovaná, jak ukazují komplikované úpravy (obr. 1). Zůstává též relevantní - nicméně nesnadno zodpověditelnou - otázkou, zda účesy vypracované s takto výjimečným umem lze zařadit do sféru zájmu antropologie umění či etnoestetiky. Jedním z inspiračních zdrojů pro zde př́tomné etnologické nahlédnutí na účesovou tvorbu byly strukturálně-funkcionalistické práce sociálního antropologa Edmunda Leache (1910-1989), jenž je i autorem klasického článku Magical Hair (Leach 1958), v němž si u vlasů všímá sdílené symboliky. Například v úkonu stř́hání vdov nevidí sebepoškozující akt - symbolickou „kastraci“ a nevědomé vybití vzteku, jak 


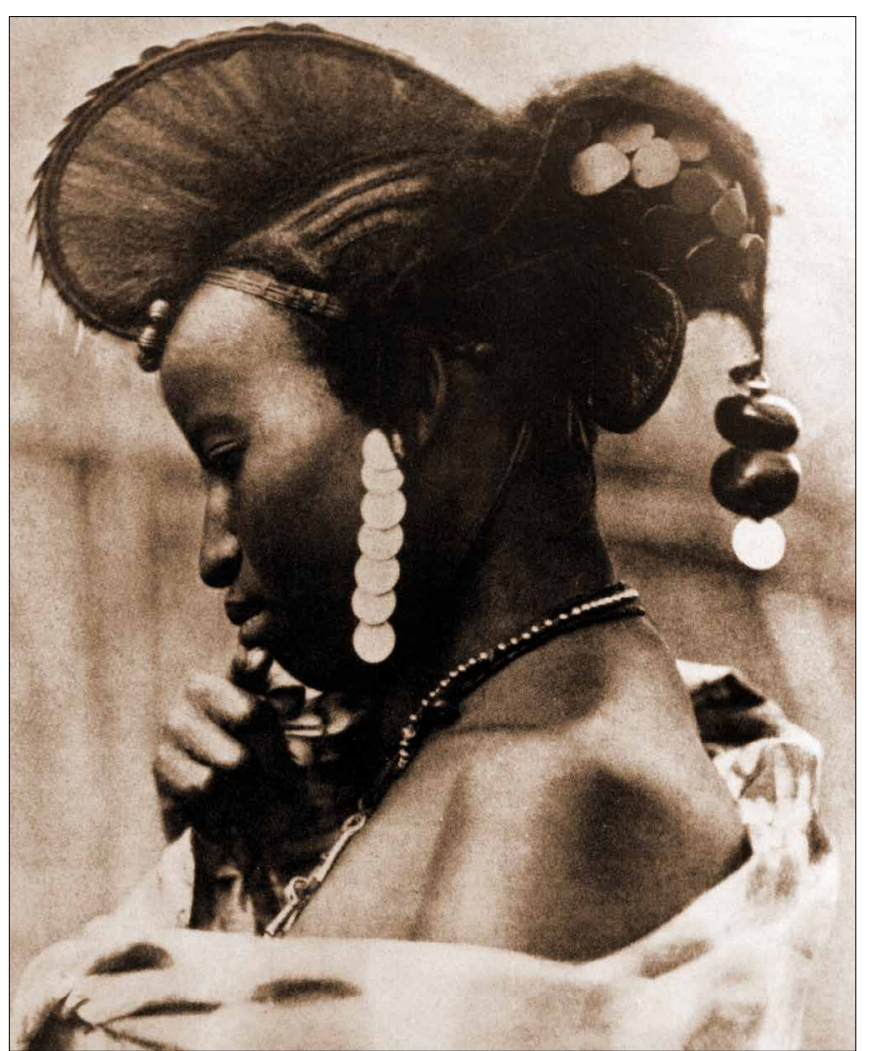

Obr. 1. Žena Fulanů/Fulbů s ozdobeným účesem z tehdejší francouzské Guineje. Počátek 20. století. (Foto: F. R. Roberts).

se domníval další klasik „teorie vlasů“ a psycholog Charles Berg (Berg 1951) - nýbrž veřejné a zjevné vyjádření vztahu k zemřelému. „Rituál oholení vlasů je druhem komunikace. Vdova podstupuje sociální smrt, aby po delším odloučení došlo k ukončení svazku s př́ibuznými zesnulého. Vrací se pak do světa živých, nechá si narůst vlasy a je jí umožněno se znovu provdat. Symbolismus je sociální a veřejný, nikoliv individuální či privátní" (Leach 1958, 152).

I obyčeje spjaté s úpravou vlasů či vousů vykazují ve značné míre hlubší vyjádření symbolických postojů vlastních dané kultuře, od čehož nelze odhližet ani při pohledu na něco tak zdánlivě všedního, jako jsou dějiny (afrického) účesu $v$ diachronní perspektivè. Pro tento sumarizující článek jsem zvolil kombinaci jak relevantnich pisemných, tak dobových obrazových zdrojů, které umožňují predstavit charakteristické formy $i$ významy účesů $v$ Africe; jednak typově, areálově a dějinně, ale $i v$ „etnografické současnosti“, což je v textu akcentováno i užitím odlišných slovesných časů $v$ náhledu na africké frizúry.

Mnohé pro účesy platí i obecněji. Vlasy bývaly v mnohých kulturách vnímány jako sídlo magické energie (Frazer 1994 aj.), odkud vycházela víra v uzmuté skalpy (Axtell \& Sturtevant 1980, Anger \& Dieck 1978) a také v četná tabu během stř́ihání a pečlivé ukrývání odstřižených pramenů, aby nemohly být zneužity - $\mathrm{u}$ Ašantů v Ghaně existovaly i vlasové hřbitovy. Účesy byly omezovány pravidly, symbolizovaly (rituální) přechod do jiného věkového stupně či stavu (van
Gennep 1997, 57), přináležitost ke klanu, kmeni či etniku a co víc - posilovaly též image a sexualitu jedinců; ve většině společností účesy odlišují obě pohlaví, naznačují zdraví jedince a rovněž vzbuzují silné emoce.

Cílem této studie však není podávat transkulturní přehled významů vlasových úprav, ale zaměřit se na oblast, která je $\mathrm{v}$ účesové tvorbě výjimečná. Jde o Afriku, především pak Afriku subsaharskou nebo také „černou“ (Jiroušková \& Todorovová 2003, Kandert 1984). „Úprava vlasů a vousů tvoří snad nejpestřejší a nejzajímavější odstavec národopisu," napsal v roce 1921 v Déjinách kosmetiky magistr farmacie Emil Šedivý (Šedivý 1921, 30-31). Co se týče různorodosti účesů, Afrika jakožto kulturní areál vyniká nad jiné; podobně pestrou paletu holení, délek, podvazování, česání, tužení, nastavování i zdobení vlasů najdeme snad jen v Melanésii na Papuy-Nové Guineji, kde se takřka liší od údolí k údolí (Rychlík 2013a).

Drdoly, culíky, copánky, holé hlavy, růžky, bambule, kohouty, vrkoče. Skoro cokoliv si lze v „umění účesu“ představit, v Africe najdeme. Afrika je - pochopitelně také kvưli fyziologii vlasů svých obyvatel - kontinentem, na němž vznikaly a vznikají složité úpravy. Jakkoliv jsou vlasy vždy jedním z nejzjevnějších rysů lidské vizáže, afrických kokrhelů či lysin si misionáři či cestovatelé všímali na nejpřednějším místě (Livingstone 2006, Sieber \& Herreman 2000, Holub 1973, Stanley 1972, Battúta ibn 1961, Šebesta \& Lebzelter 1933 aj.).

„Africké účesy jsou velmi rozmanité. Mnohá etnika vynakládají množství energie, času i fantazie na vytváření těch nejbizarnějších účesů. Pro tradiční africké účesy platilo, že žádný model nebyl individuální. Jednotlivé typy účesu byly určeny pro zvláštní obřady, pro oslavu štastných událostí, jako je přechod z věkové skupiny do jiné, sňatek nebo narození dítěte. Dále byly účesy nošeny jako symbol společenského postavení (Jiroušková \& Todorovová 2003, 16). Př́kladem je právo chotí beninského vládce (oba); nikdo se nesměl bez svolení učesat stejně jako manželky (iloi), jež si pro slavnosti nasazovaly i paruky.

Běžné bylo odlišování pohlaví, leč od europocentrických zvyklostí jiné, takže například u Masajů v Keni mají vyholenou hlavu ženy a děti, kdežto muži se zdobí copánky. Po skončení věkového stupně „válečníka“ jim matky oholí hlavu (obr. 2), natřou ji červení, což mužové opláčou, nebot’ opouštějí nejzábavnější životní etapu (Jiroušková \& Todorovová 2003, Sherrow 2006, Fisher 1984 aj.). Jak se Evropané a další cizinci seznamovali v běhu času s africkými účesy, ukazuje následující část.

\section{NEJSTARŠÍ HISTORICKÉ DOKLADY}

Nejstaršími doklady, že se Afričané o vlasy starali, jsou skalní malby, zejména ty v alžírském Tasíli-n-Ažžer. Některé postavy mají vousy do špičky i vysoké účesy - jako je tomu na malbě z Tisukai, z bovidiánského období (asi 3200 let př. n. 1.). „Zobrazuje skupinu žen s velmi elegantními účesy. Všechny mají velmi složité účesy s pštrosími pery“ (Lhote 1982, 278). Desítky postav naznačují úpravy hlavy, nošená pírka nebo květy 


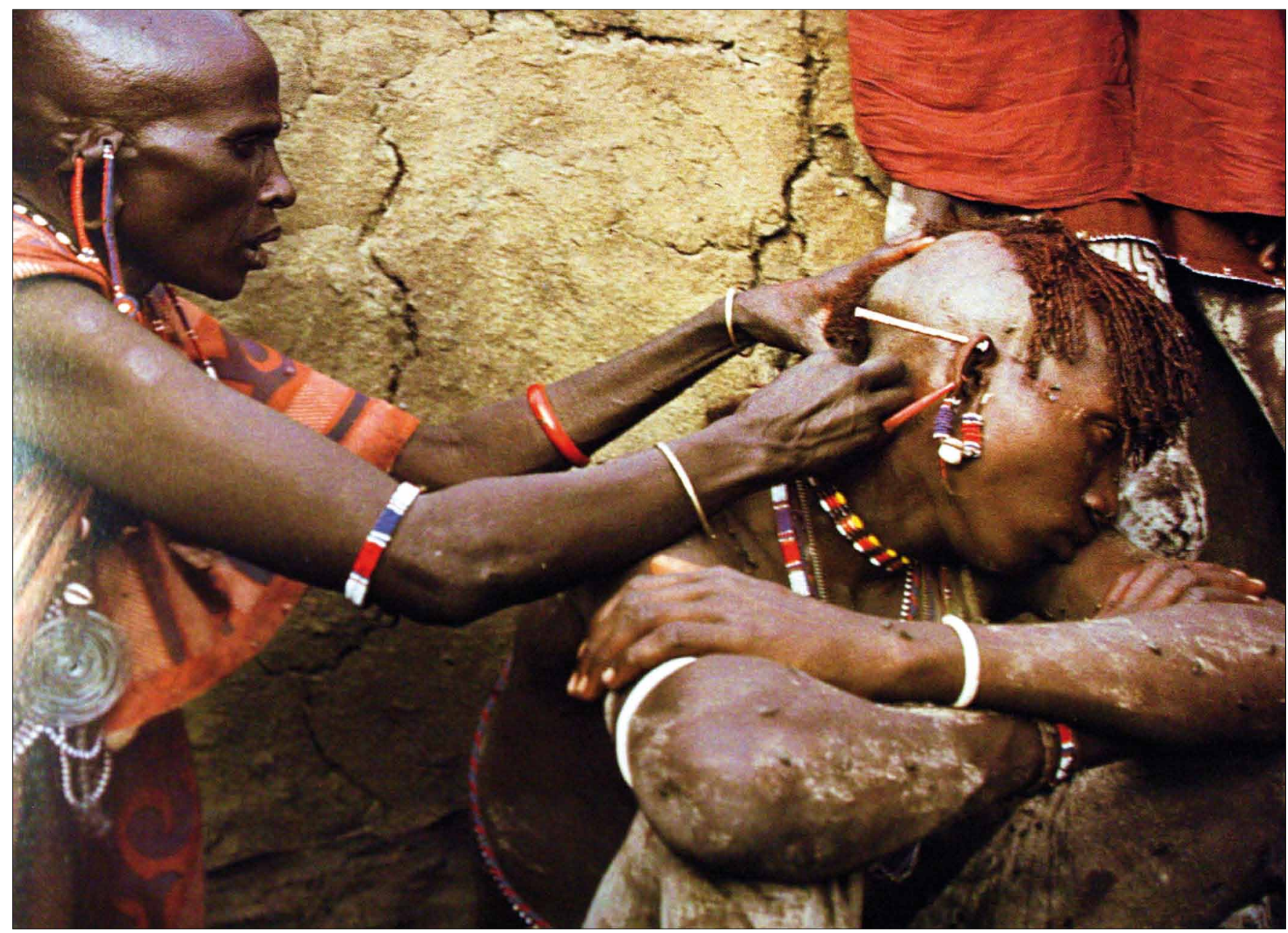

Obr. 2. Matka holí hlavu svého masajského syna, nebot ten opouští klíčovou etapu života a přestává být bojovníkem. Masajové, konec 20. století. (Foto: Angela Fisher).

ve vlasech, jak je vidět na výjevu sedícího muže s dívkou ze Sefaru. Vysoký účes má i tamní bojovník.

Objevitele maleb Henriho Lhoteho zaujala podobnost zobrazených pastevců, rituálů i žen (s vlasy upravenými do chocholů či homolí), jež stejně jako malby mužů s propletenými prameny odpovídaly Fulbům. Třeba v Žabbárenu má jedna $\mathrm{z}$ dam zploštělý účes, přesně takový, jako se to stává fulbským ženám, když sejmou výztuž, jež jim drží vlasy. Na dalším obraze „účes patrně označuje vznešenou osobnost. Nacházíme tu čelenku - či baret - této školy, ale vršek účesu je jiný a zdá se, že nese odznak, který se tvarem podobá egyptskému pschentu, “ což byla koruna faraónů (Lhote 1962, 175). Lhote na základě ikonografické shody v účesech předpokládal migraci Fulbů, stejně jako kontakty se starověkým Egyptem. Účesy dávných Egyptanů - včetně jejich složitých paruk - jsou ale samostatným námětem, jemuž se zde věnovat nebudu a činí tak bohatá literatura jinde (Rychlík 2013a, Verner, Bareš \& Vachala 2007, Fletcher 2002, Strouhal 1989, Erman 1971 aj.) Už Hérodotos se v 5. století př. n. 1. při popisu "Libye“ (čili celé tehdy známé Afriky) zmínil o národech za hranicemi
Egypta. První byli Adyrmachovci, kteří nosili dlouhé vlasy a rozkusovali a zahazovali vši - jako jediní z „Libyjců“. Etiopané měli rovné vlasy. Dále na jihu žili Garamantové. „V prřímoří od nich na západ s nimi sousedí Makové, kteří si dělají chocholy tak, že nechávají uprostřed hlavy vlasy růst a kolem dokola je holí až na kůži“ (Hérodotos 2004, 276). Následují Machlyové, kteří si nechávali růst vlasy vzadu, kdežto Auseové vpředu. Na západě žili Maxyové, kteří měli dle Hérodota kadeře pouze na pravé straně hlavy (Hérodotos 2004).

Zdá se tedy, že v Africe vznikaly pro cizince „šokujíci“" účesy už před více než 2500 lety, ale roztodivným tvarům se podivovali i stále četnější cestovatelé, kteří $\mathrm{k}$ africkým břehům putovali o mnoho let později. Holandan Pieter de Marees v knize o „Zlatém království Guineje“ (1602) popsal hned šestnáct rozdílných účesů. Na Zlatém pobřeží se nosily i vyholené kř́ǐze a měsíčky nebo kučeravá číra; v Beninu se ženy dle Nyendaela (1699) zdobily jakoby „obrácenými kohoutími hřebínky“ (asi pruhem uprostřed) a rovněž směsmi z palmového oleje, jež prý černé vlasy měnily na zelené a žluté (Sieber \& Herreman 2000). 


\section{NOVĚJŠÍ PÍSEMNÉ ZMÍNKY}

Asi nejstarší poznámku o účesech černé Afriky učinil Portugalec Cado Mosto (1455), když popsal Wolofy (Djolofy) na řece Senegal. „Obě pohlaví chodí bosa a nezakryta, leč pletou si vlasy své do krásných vrkočů, jež splétají do rozličných culíků, ač ty krátkými jsou“" (cit. dle Sieber \& Herreman 2000, 19). K sousedním Azanaghiům dodává: „Nosí vlasy, jež jsou černé, zastřiženy nad rameny, jako Němci; a mazají je každý den lojem $z$ ryby, pročež velmi páchnou; nicméně to považují za libé“ (Sieber \& Herreman 2000, 19).

O půlstoletí později se Diego d'Azambuja, zbudovatel pevnosti Elmina, zmiňuje prvně o africkém vousu, když popisuje Karamansu, „krále Guineje“, jehož vous byl zdoben množstvím zvonečků. Další psali o šedých bradách starců, kteří požívali úcty: náčelník Issini z Pobřeží slonoviny měl dle Loyera vous spletený do dvaceti cůpků.

Nejvíce zmínek pochází ze západního pobřeží, kolem nějž Evropané připlouvali (Kandert 1984). Clémenta Jannequina (1643) zaujaly ozdoby Wolofů či Mandingů, kteří si do krátkých vlasů vplétali amulety (grisgris), stříbro, kůži i korály. Potomci otroků si nesměli vlasy nechat růst. Naopak dle Brüeho (1715) si královy sestry v Senegalu spínaly účes jehlami, vyzvedávaly nad čelo jakousi pyramidu a šlechtily si obočí, jež natíraly olůvkem. Účesy byly někdy barveny do červena. Když dámy účes svědil, užívaly zlatých drbátek.

Už rané zmínky potvrzují rituál postřižin. V Senegalu tak bylo kolem roku 1730 stříháno jedenapůlměsíční dítě. „Pojmenovávají to děcko spolu s holením hlavy jeho a vtíráním oleje, přičemž zvou šestero přátel, aby se stali svědky, “ zapsal Francis Moore, který fulbské účesy přirovnal ke splétané koňské hřivě (cit. dle Sieber \& Herreman 2000, 18). Další z objevite-

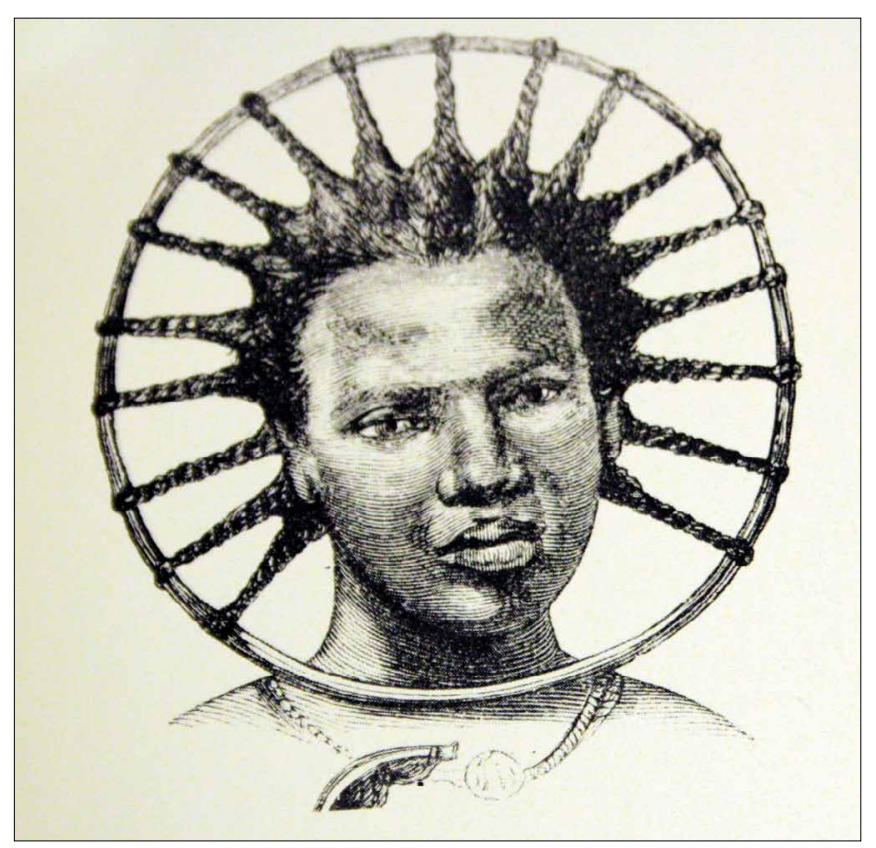

Obr. 3. Žena z někdejšího Zairu s bambusovou „svatozáří. Nedatováno, patrně 19. století. (Kresba: anonym, dle Fisher 1984, 68).

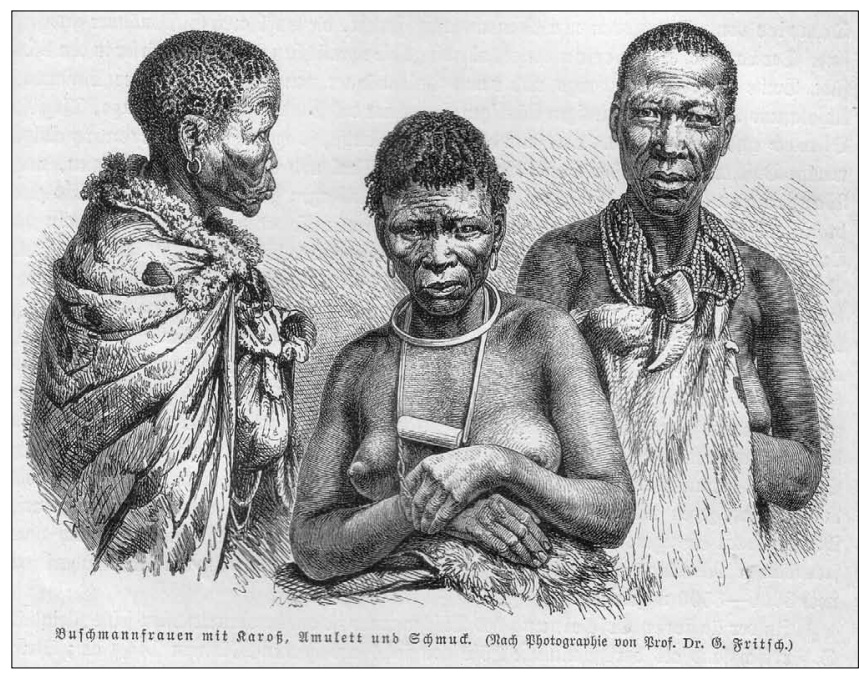

Obr. 4. „Ženy Křováků“. Nedatováno, konec 19. století. (Kresba: dle fotografie pro kompendium Friedricha Ratzela).

lů popisují iniciační holení hlavy u tajné společnosti „Sandi“ na Pepřovém pobřeží (dnešní oblast Sierra Leone a Libérie). V 17. století vzkvétal v Africe obchod. A kupčilo se tam i s vlasy. Willem Bosman (1702) psal o Guinejcích: „Baží po parukách, jež nosí, ovšem nosí je skličujícím způsobem. Dříve tu námořníci čile obchodovali se starými parukami, za něž dostávalo se jim vosku, medu, papoušků, opic; veškerého občerstvení, po němž při výměně prahli: ale za to čtvero roků zde pobývalo tolik obchodníků s vlásenkami, že obchod je již zmařen“ (cit. dle Sieber \& Herreman 2000, 59).

I v takové kapitole dějin, jakou je obchod s otroky, hrály roli vlasy. Musely být krásné, zdravé. Jean Barbot popisuje na Zlatém pobřeží jednu z „přejímek zboží. Nazí otroci byli vyvedeni, aby je ranhojiči prohlédli. „Jejich pozornosti neujde jediné místečko na těle. Ti, kteří jsou uznáni jako zdraví, postaví se na jednu stranu, a na druhou ti, kteří byli odmítnuti. Nepřijatí otroci se jmenují ,makroni' a jsou zamítnuti, protože jsou starší než 35 let či mají vadné rty, nemocné oči, zkažené zuby, šedivé vlasy či jiný defekt“ (Davidson 1964, 108). Následně byli ocejchováni žhavým železem a nastoupili cestu do Nového světa.

Bílý muž - často zvaný muzungu - postupoval do útrob světadílu. Dle Burtona se v půli 19. století setkali běloši v západní Africe i se zvykem skalpování; tvrdil to John Duncan v letech 1845-1846. Ale na očích byly spíše účesy. Botanik G. A. Schweinfurth u Ňam-Ňamů (Zandů) popsal mužský účes: „Hlava jim byla upravena po způsobu, jak u nás hlavy svatých a světic korunou zářnou se krášlí. Pletence vlasové byly napjaty na kruhu, ozdobeném mušlemi; čtyry dráty přidržovaly jej ku spodnímu kraji klobouku“ (cit. dle Vlach 1911, 46).

Roku 1854 zaznamenal cestovatel David Livingstone podobný účes u Lundů v Angole. Dívka měla obruč, do níž byly po obvodu obličeje vpleteny copánky, jež „svatozár““ spojovaly s kráskou (obr. 3). Při cestě po Zambezi v letech 1858-1864 zapsal, že si muži ostř́ihané vlasy schraňují, spálí je nebo zakopou, aby se nedostaly nepovolaným do rukou. Co se týče 
účesů, „varianty byly nekonečné. Jeden si dlouhé lokny přejíždí tak dlouho, až nabudou tvaru buvolích rohů, jiní si je raději nechávají v tlustých provazcích spadat na záda jakožto ohony zviřat; zatímco další nosí kroucené pramínky, jež trčí z hlavy do všech stran“ (Livingstone 2006, 50).

\section{VLASY !KUNGŮ A PYGMEJU゚}

Obecně černochům nerostou př́liš dlouhé vlasy; délka kolísá mezi několika až desítkami centimetrů. Asi 75 procent obyvatel má vlasy kudrnaté, zbytek kroucené. Unikátem - nejen dle vlasů - jsou Sanové či !Kungové, jimž se ř́kalo pejorativně Křováci, kteři žijí na jihu v poušti Kalahari. Tito lovci a sběrači patří $\mathrm{k}$ nejarchaičtějším populacím světa. Ač jsou vlasy !Kungů kratounké, i na výjevech skalního umění starého stovky let najdeme též postavičky s účesy. Šedivě naznačené čupřiny mají lovci z hory Ikanti v Drakensbergu (Natal), péra ve vlasech nesou figury $z$ Ebusingaty, Mpongweni, oblasti Kambergu nebo „lučištník z Bosworthu poblíž transvaalského Klerksdorpu" (Willcox 1963, 70).

!Kungové stejně jako sousedští Khoinové (Hotentoti) mají vlas huňatý a hustě rostlý v malých, pepřovitých chomáčcích (obr. 4). Křovácké vlasy jsou dlouhé nejvýše 1,5 centimetru, takže vytvářejí nízkou čepičku. Ochlupení je slabé. „Krátké, do pepřových zrnek rostlé vlasy žen byly prodlouženy copánky z jemných černých vláken, obratně do nich vpletenými a spadajícími v pramíncích na hladká ramena" (van der Post 1967, 129). Ženy vyráběly z pštrosích skořápek korálky, jež pak navlékaly do náhrdelníků a zářivých čelenek. Hotentotské účesy se dle Kolbena (1713) odedávna schovávaly pod slupkou popela a tuku, která je měla v parnu ochlazovat, takže si tyto vrstvy nanášeli denně na hlavu. Stateční muži, kteří zabili lva či levharta, si mohli vetknout nezvyklou ozdobu: „Ve vlasech připevněný měchýř šelmy, jíž zabili, jakožto odznak cti“ (cit. dle Sieber, Herreman 2000, 23).

Výjimeční jsou také Pygmejové. Psal o nich již Hérodotos, dle nějž šlo o lid menšího než prostředního vzrůstu a černé pleti. Byli ze „země stromư“, tedy pralesa, dováženi do Egypta, kde budili senzaci (Hérodotos 2004). Až roku 1863 viděl pygmejské trpaslíky na vlastní oči Evropan - v gabunském pralese se to povedlo Paulovi du Chaillu a sedm let nato si Schweinfurth „černouška“" Nsevueho dovezl do Chartúmu.

Pro poznání pygmejských populací je důležitý podíl misionáře a antropologa Pavla Šebesty. Na řece Ituri, kde podnikl ve dvacátých a třicátých letech 20 . století terénní výzkumy, získal přezdívku „Baba va Bambuti“ čili Otec Pygmejů (Šebesta \& Lebzelter 1933).

Sám Šebesta po prvním kontaktu přiznával, že iturští Bambuti „byli oškliví; první mužíček Agali jej zaujal postavou, zamračenou tváří, hustými vousy a huňatým obočím. Měřil 145 centimetrů, což byl tamní průměr. Nejmenší žena, jakou etnograf potkal, měla pouhých 118 centimetrů. Svárlivým skřítkům na kráse neprridal ani zvyk sesekávat si zuby do špičky, aby se lišili od zvířat. Zvykem žen bylo vytrhávání řas, nikoliv ale obočí.

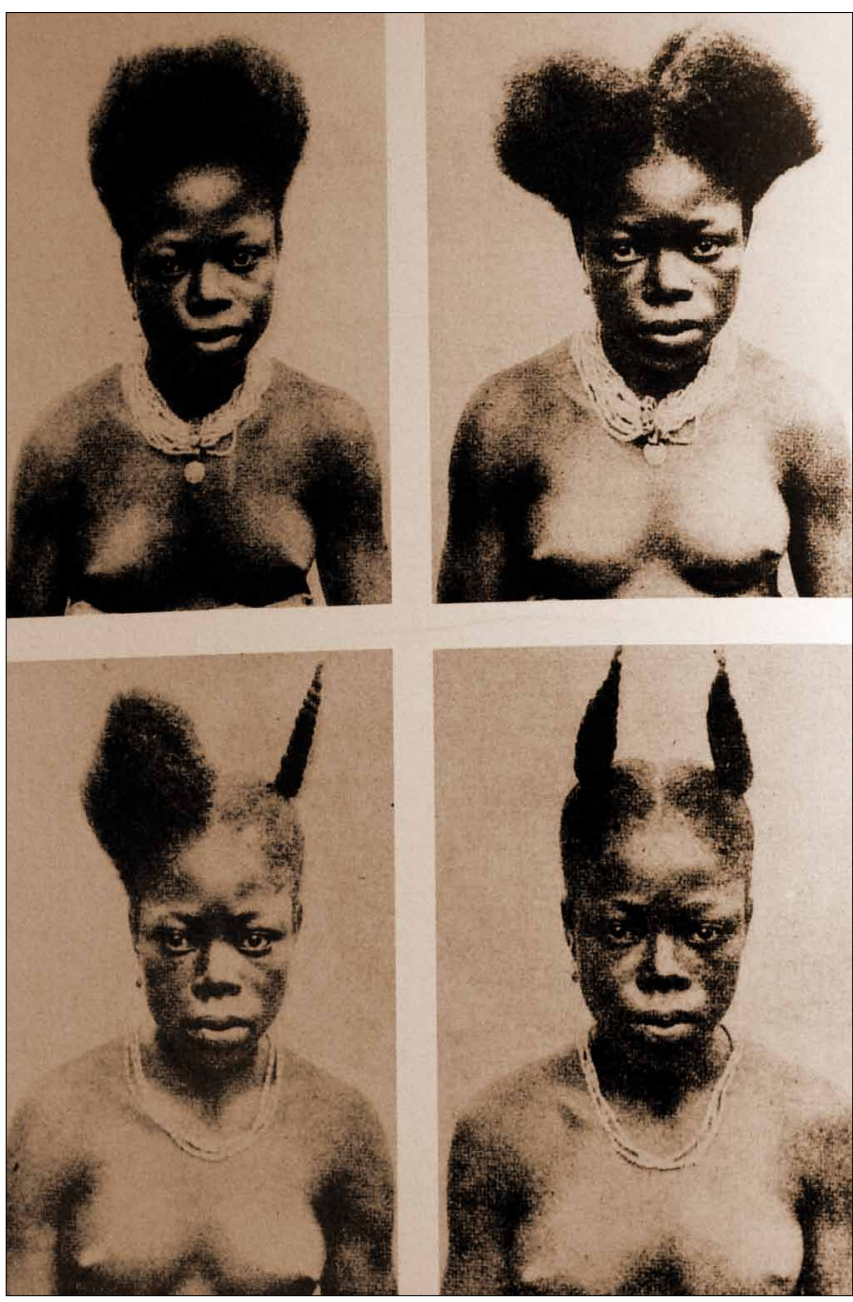

Obr. 5. Několik fází vlasových úprav. Fanti, Ghana. Nedatováno, patrně začátek 20. století. (Foto: archiv autora).

Vlasy měli Pygmejové černé, spirálovitě točené, ale krátké nejvýše do čtyř centimetrů. Ženy a starci se vyholovali dohola, zato mužové si nechávali roztodivné ostrůvky $\mathrm{z}$ pačesů. Třeba Agomu měl pouhý asymetrický proužek vlasů, jiní mladíci se pyšnili osamělým chomáčem nad čelem (Šebesta \& Lvová 1956).

Šebesta popsal ranní toaletu: „S předkloněnou hlavou sedí A-Kundi-Kvelu pred dívkou, která obtahuje nožík o dlaň a vyholuje jím na jeho hlavě nejpodivnější vzorce. Počíná si zručně. Vedle ní leží střepina s vodou, do níž namáčí špičky prstů a navlhčuje jimi místa na hlavě, která mají být vyholena. Šmik, šmik, šmik, a chomáče kudrnatých vlasů padají na zem! Účes je stále fantastičtější. Na temeni se objevil vzorec půlměsícovitého tvaru, v týle větší a podobně. Zdá se, že tu rozhoduje dívčí vkus. A-Kundi-Kvelův príklad táhne, nebot vidím stále více chlapců a mladíkư, jak sklánějí hlavy do klínů krásek, které zručně operují holícími nožíky... Pygmejové nenosí ozdobné hřebeny“ (Šebesta \& Lvová 1956, 190). Muži si vlasy, jejichž vzorky zaslal Šebesta do Hrdličkova muzea v Praze, zdobili péry či střapci ze štětin vepře. 


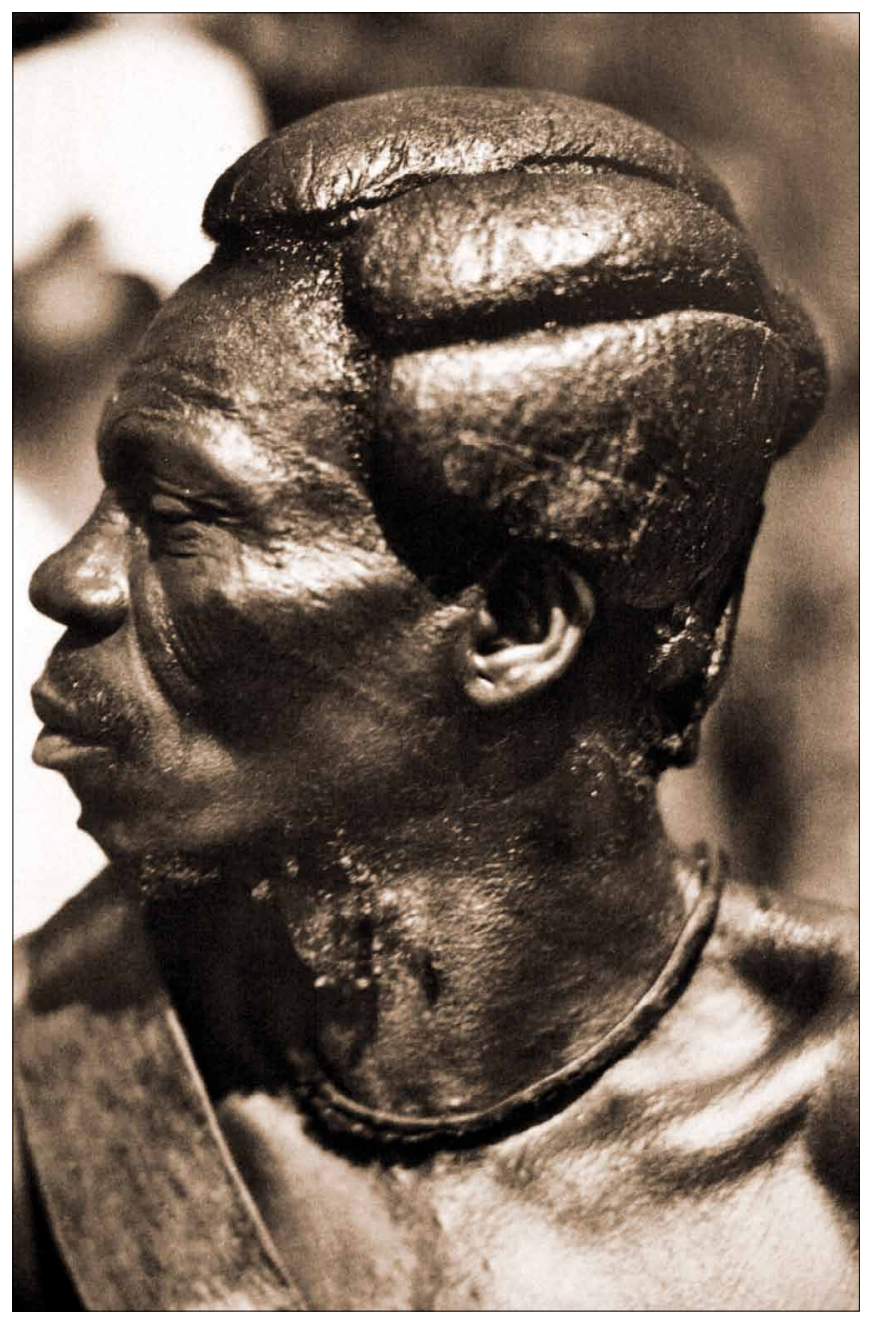

Obr. 6. Muž Banzů, dnešní Demokratická republika Kongo. Někdy mezi lety 1926 a 1937. (Foto: Zagourski, dle Sieber \& Herreman 2000, 31).

\section{TYPY ÚČESŮ SUBSAHARSKÉ AFRIKY}

Nejpestřejší účesy nabízí subsaharská Afrika (Sherrow 2006, Jiroušková \& Todorovová 2003, Sieber \& Herreman 2000, Kandert 1984 aj.). Oblast obývají lidé s hustým a chundelatým vlasem (obr. 5), z nějž se dají vyrábět takřka umělecká díla. Etnoložka Jiřina Todorovová (2003) rozeznává v tzv. černé Africe čtvero účesových typů: modelované, copánkové, volné a vyholené. Do první kategorie patří ty, k jejichž vzniku bylo užito pomocných prostředků - jako je tvarování hmotami (dobytčí trus, velbloudí máslo, hlína, tuk, popel) nebo zaplétání výztuží (obr. 6). Př́prava trvala dlouho, ale vlasové kreace vydržely celé týdny; důvodem jsou pochopitelně i hygienická opatření, protože různé pasty s príměsemi fungovaly též coby prostředky proti vlasovým parazitům a hmyzu.

„Modelované účesy mohly mít nejrůznější tvar - můžeme je označit jako kloboukové (takové nosili muži Šiluků v Súdánu), paprskové, pláštěnkovité (vlasy tvořily pláštěnku splývající po zádech a zdobily muže Karamodžong a Suk žijících na hranici Ugandy a Keni), kuželovité, věžovité... Vlastní vel- mi krátké vlasy byly doplňovány příčesky $\mathrm{z}$ rostlinných vláken (sisál, lýko, vlákna z palmových listů, rozmočené dřevo baobabu), ze shromaždovaných lidských vlasů nebo zvírecích chlupů (kozích)“ (Jiroušková \& Todorovová 2003, 110-112). $\mathrm{Z}$ téhož materiálu se vyráběly i paruky, které patřily hlavně ke slavnostem a obřadům.

Ač nebyli Afričané obdařeni dlouhými vlasy, umějí si vypomoci. Činí tak prostřednictvím přičesků a doplňků (obr. 7). Vycpávky a konstrukce jsou z bambusu, dřeva či košíků. A nebylo výjimkou, že před kadeřníky ležely mísy s nastř́íhanými kadeřemi, které zaplétali do účesu. O nastavovaných účesech píši už mořeplavci jako Barbot (1679) nebo Phillips (1693), dle nichž se užívalo jak vláken, tak vlasů. „Byly to kadeře jejich manželek, jež jich odřízly, aby mohly být takto vpleteny," píše Barbot (cit. dle Sieber \& Herreman 2000, 20). Ženy Mbumů v Kamerunu nosily příčesky, jež aranžovaly do šesti vztyčených rohů, ale nosily i vytrčenou dvojitou věž o výši až půl metru. Dámy z téže oblasti měly z přidaných vlasů jakési střapce po stranách. Slečny Ibů svým jílem natuženým kokrhelem naznačovaly, že by se klidně i rády vdaly a dámy malijských Songhajců a Bellů si do copánků vplétaly trsy žirafí hřívy.

V západní Africe se užívalo různých vycpávek a podložek. Turkanové a Pokotové $z$ Keni/Ugandy dávali přednost „fasádováni“" vlasů. „Jejich př́slušníci si stáhli vrstvy vlasů a zformovali je hlínou, která vytvořila skořápku. Dříve prý takové mužské ,závoje' ze ztvrdlé hlíny byly ještě delší a Masajové si

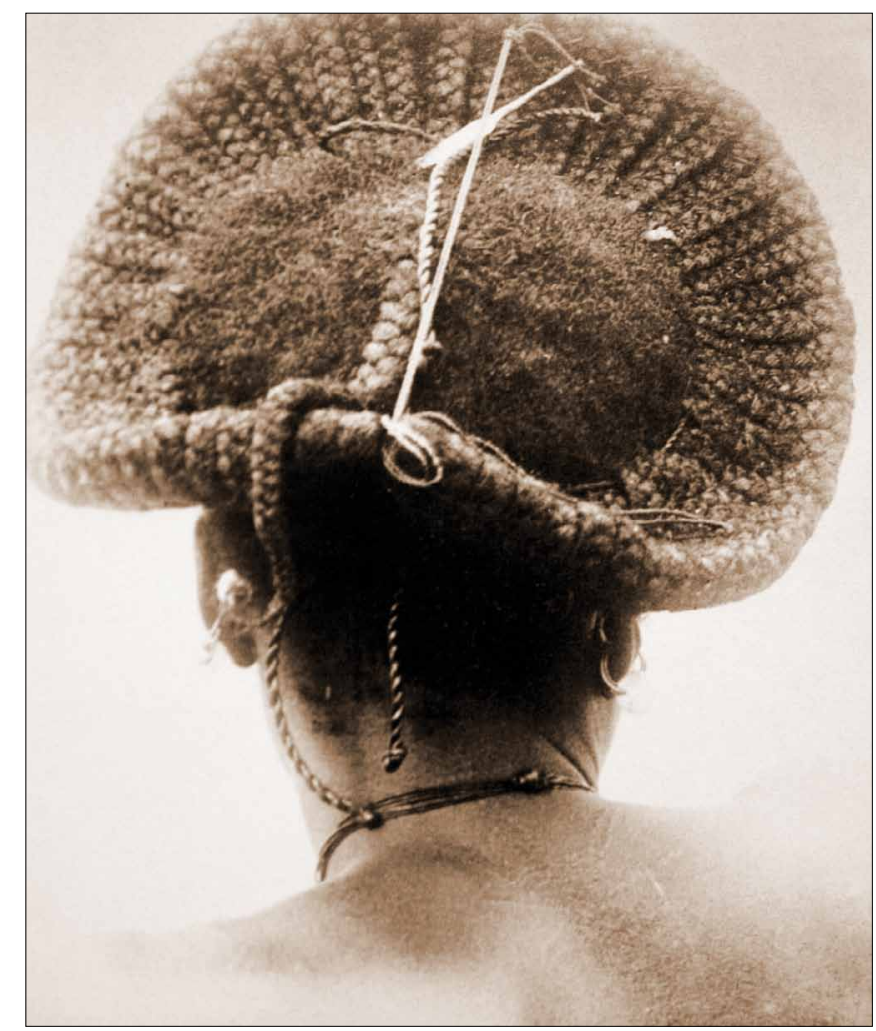

Obr. 7. „Žena náčelníkova“. Etnikum Sande, Bambili, v roce 1912. Dnešní Demokratická republika Kongo. (Foto: A. Hutereau). 


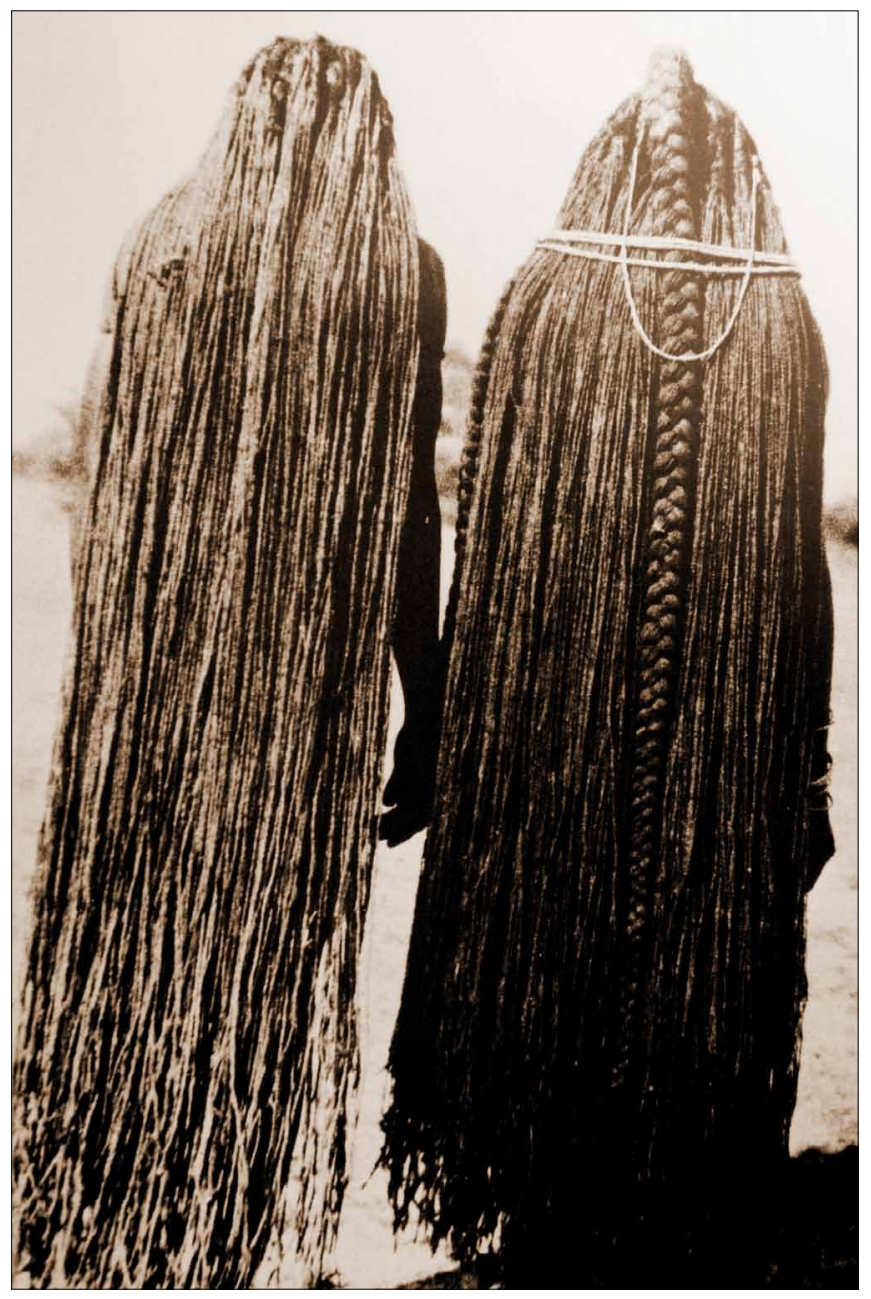

Obr. 8. Paruky z umělých provazců i šlach. Skupina Mbalantu, Wambo. Dnešní Namibie, kolem roku 1940. (Foto: M. Schettler).

své copy prodlužovali srstí skotu. Hliněná ,pleš’ byla sytě barevná: u Pokotů směl mít jen dospělý muž azurově modrou blátivou čepičku, kdežto nezasvěcený mladík nanejvýš okrově červenou“" (Klíma \& Kubica 1983, 105).

Banzové si uplácávali masivní př́lby, rozdělené do podélných pásů o výšce dvou palců. Matky Rendilleů z Keni si po porodu prvého syna vyráběli z bláta a tuku vysoký hliněný „hřeben“ na temeni. Zuluové vlasy proplétali rostlinnými vlákny a zpevňovali je hlínou s tukem, což umožnilo vytvoření ojedinělých tvarů - třeba účesu ve tvaru lodního šroubu. A ženám Sangů z Konga splývaly umělé hřívy až nad zadek, což překonaly paní z Namibie (Fisher 1984). Př́́slušnice skupiny Mbalantu kmene Wambo (obr. 8) si ještě ve čtyřicátých letech 20. století vyráběly vlasové závoje s obřími copy po kotníky (Sieber \& Herreman 2000).

Druhým typem jsou dle Todorovové copánkové účesy. Z vlasů se splétají tenké i silnější copánky, které se utáhnou a promažou tukem, aby držely tvar (obr. 9). „Copánky mohou být pevně přilehlé $\mathrm{k}$ hlavě anebo splývat až pod pas, nastaveny vlákny (sisál, lýko) nebo zvírecími šlachami či chlupy. Zaplétání je časově náročné; trvá i více než šest hodin. Česaná žena proto většinou leží, a úprava účesu se stává příležitostí k odpočinku a konverzaci. V Nigérii nebo v Súdánu platí - čím více copánků, tím více elegance. Počtem copánků se řídí i cena účesu“ (Jiroušková \& Todorovová 2003, 114). Takto trvanlivý účes stačí zaplétat pětkrát do roka.

Působivě si splétají vlasy Masajové. Muži mají na hlavách cůpky, na čele a skráních se spojují, přičemž největší cop visí dolů na záda a býval zdoben korálky. Kompletní účes, který vynikl díky vyholeným čelům, se natíral tukem a hlinkou. Hererkám trčely do obličeje dva copy hustě promazané hlínou, takže budily až „kamenný“ dojem. Jihoafrické ženy Sotho si pletly uprostřed temene jakési řasené „číro“, zatímco si skráně čistě holily. A z konce 17. století máme ve Phillipsově díle nejspíše i první zmínky o zcuchaných dredech.

Do třetího typu spadají volné nebo sepnuté, málo upravované účesy. Aby byl odpuzen hmyz, většinou se vlasy natíraly žluklým tukem. Čtvrtým druhem jsou holené vlasy; časté řešení vlasové péče (Sherrow 2006). Bezvlasé chodily Masajky, ale i jejich sousedky z kmene Kikuju. Dle Coleho, jenž působil u keňských Samburů, se ženy holily, zatímco si muži stáčeli vlasy do stovek tenkých cůpků a konečky spojovali v „prasečí ocásky“ dřevěným přivěskem, nebo vytvářeli z rudkou barvených vláken vytrčený „kšilt" - ilmasi wala.

Hlava nemusela být úplně holá. Už před rokem 1607 se dle Finche v Sierra Leone ženy holily, ale muži si vytvářeli př́ičné

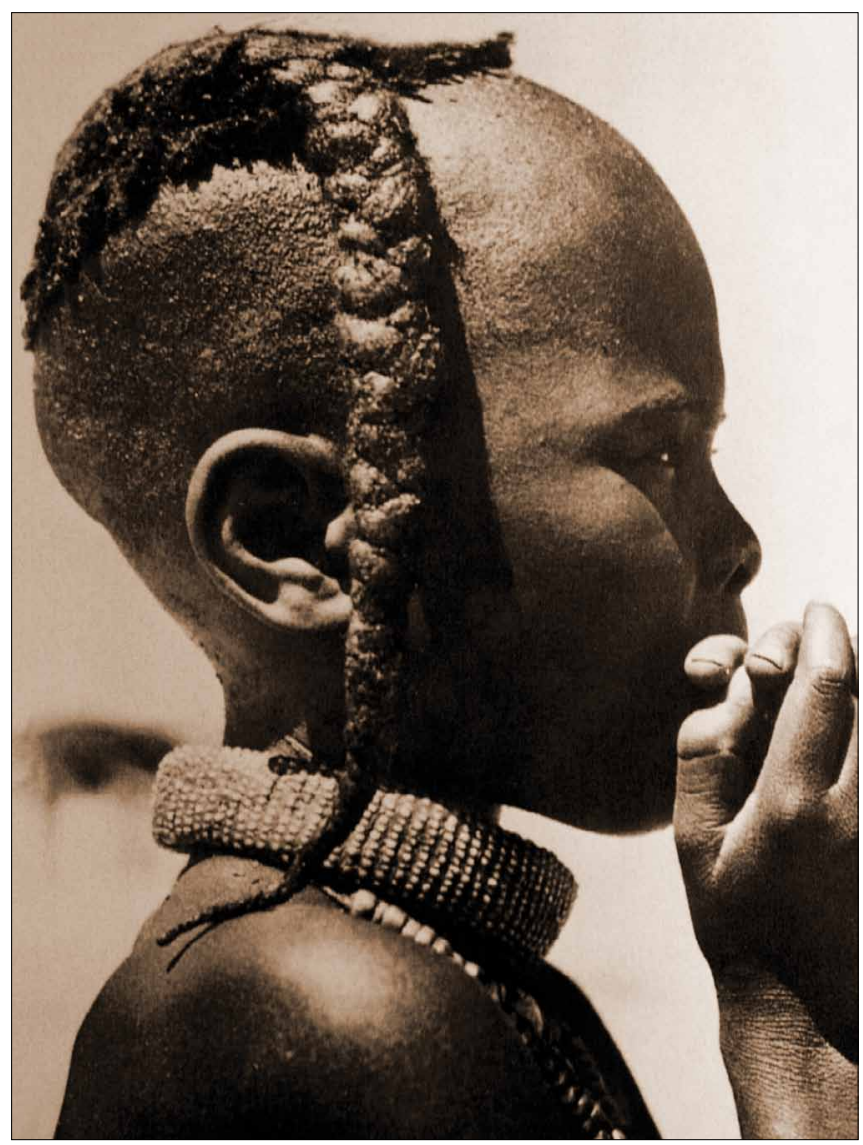

Obr. 9. Chlapec s cůpkem. Himbové, Namibie. Čtyřicátá léta 20. století. (Foto: Anneliese Scherz) 


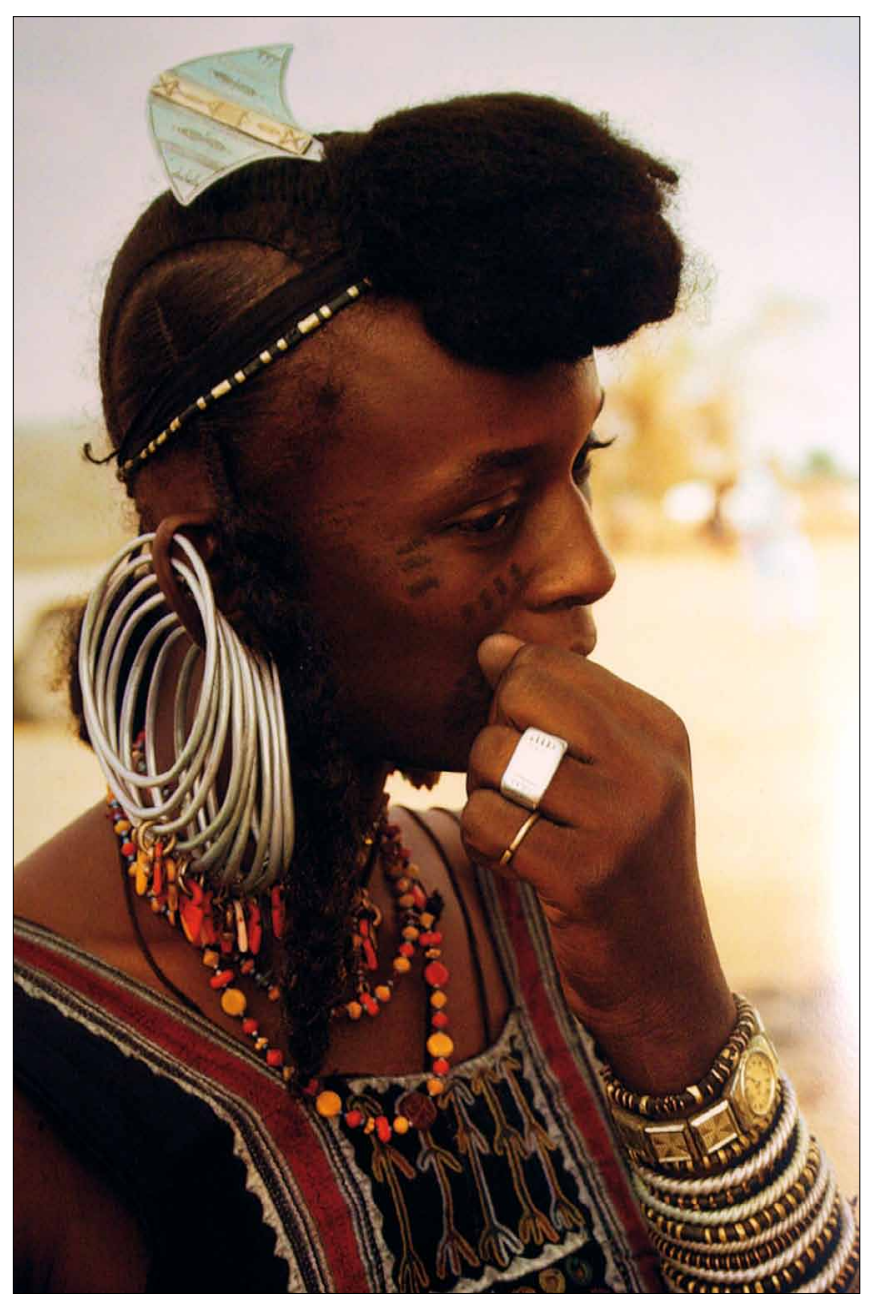

Obr. 10. Místní krasavice s vyčesaným chocholem. Fulani/Fulbové (Wodaabe), konec 20. století. (Foto: Angela Fisher).

pruhy, mezi nimiž zůstávaly čtvercové chomáče. O staletí později si dámy Mende vyholovaly podélné proužky, mezi nimiž se rýsovaly řady copánků. Kuramové z Nigérie si nechávali jediný chomáček, jasný to etnický znak. Děti Fulanů-Bororo (Fulbové) vypadaly s vyholenými kusy lebky, jako by trpěly kožní nemocí, zatímco dívky nosily uprostřed čela pěkně vyčesaný chochol (obr. 10). Malí Turkanové měli kohouty vedoucí od čela až po zátylek. Časté byly šošolky u dětí; chomáč s cůpky na lebeční fontanelle kamerunských dětí Mambila je měl domněle chránit před vstupem zlých duchů (Fisher 1984 aj.).

\section{HOLUBOVO INTERMEZZO U MAŠUKULUMBŮ}

Čechem, jenž pronikl do nitra neprobádané Afriky, byl Emil Holub. Už při své první cestě v roce 1875 slyšel o tajemném kmeni Mašukulumbů. Šlo o bantuské Ily žijící v Zambii. A už tehdy se s šesticí vyslanců setkal (Kandert 1984, Holub 1952 aj.).

„Mašukulumbové pyšní se nejvíc svým vlasem, který jest hoden podivu. Na temeni spočívá bud' celý, nebo zkomolený kužel, jsa s hlavou spojen. Některé vrstvy složeny jsou $\mathrm{z}$ vodorovných rulíků, jiné $\mathrm{z}$ kolmých, jinde $\mathrm{z}$ překřížených a jinde $z$ rovnoběžných, jež uměle jsou spleteny a roztokem klovatinným napuštěny, takže vypadají, jako by to byla stavba zbudovaná ze samých vlasů majetníka; ale není tomu tak. Mašukulumbové oškrabují si totiž občas huňatý vlas kromě okrouhlého 30 až 35 centimetrů dokola“ (Holub 1952, 185-186). Potřebné vlasy získával majitel od svých žen, otroků, poražených soků nebo je nakupoval. Nejvyšší z vrkočů, které Holub u ambasadorů viděl, měřil 103 centimetrů!

Při další expedici v letech 1885-1887 se Holub s mašukulumbskou kulturou seznámil blíže, než si př́l. Vzal s sebou oddanou manželku Růženu, jež u černochů budila vzrušení plavými vlasy. S postupem na sever si Holub všímal, že je péče o vlasy čím dál svědomitější a každý copánek si lidé mastí. Opět jej, coby amatérského etnografa a dodavatele muzejních kuriozit (od Mbundů získal pro Náprstkovo muzeum v Praze i dřevěný hřeben), zaujaly obří drdoly - statusové symboly. Při prvním kontaktu s Ily u vsi M’Beze se nad trávou míhal jakýsi trychtýřr, takže se Holub divil, co se děje. Hle, byl to mladík s vlasovou „věži“ na hlavě.

Všichni muži Mašukulumbů prý nosili „drdoly“ o výšce 30 až 40 centimetrů, které se vypínaly kolmo nebo šikmo vzhůru a prodlužovaly týl (obr. 11). Ženy mívaly hlavy hladce oho-

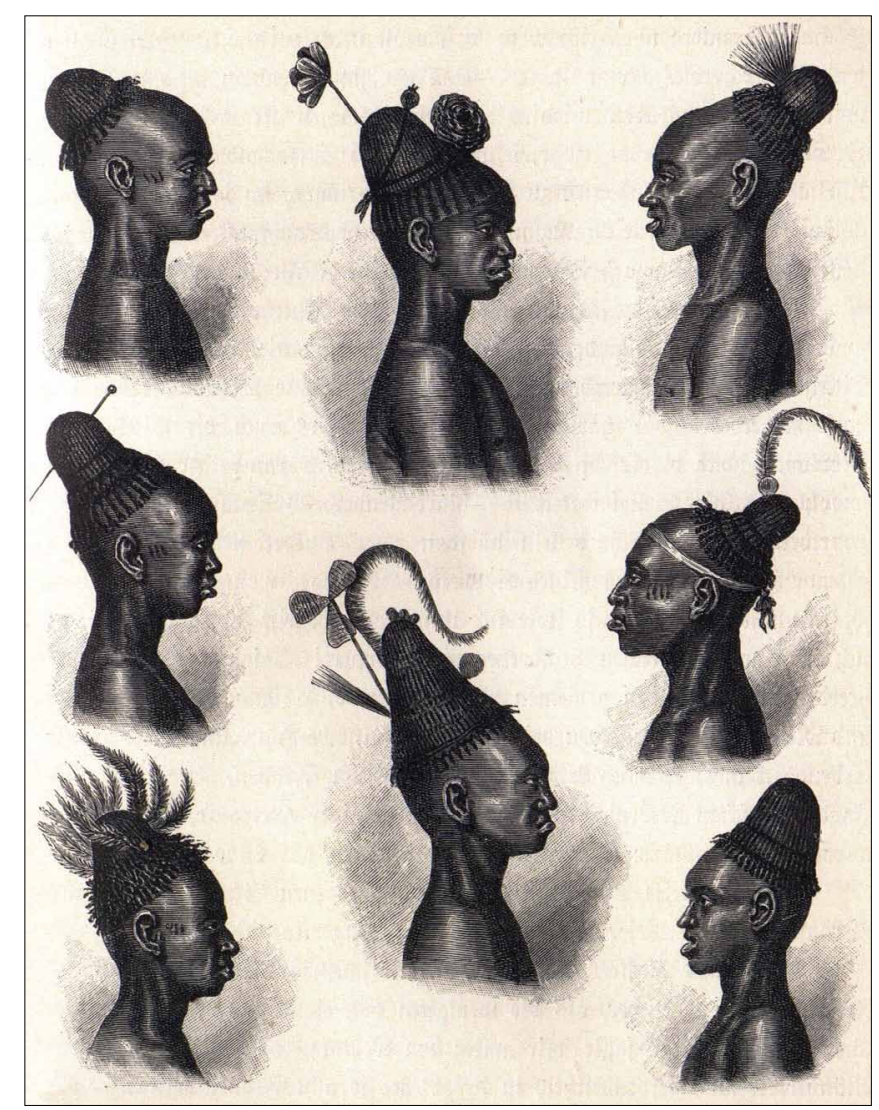

Obr. 11. Účesy „Holubových“ Mašukulumbů, 19. století. (Kresba: dle Emila Holuba). 
lené; pouze dívky do dvanácti let se zdobily copánky. Stejně staří hoši měli na temeni pouze chocholku, asi budoucí základ vlasových homolí. Staříci je již také nenosili. „Při úpravě vrkoče natírají vlasy tukem a nasypávají do nich kovový prášek, takže vlasy nabudou lesku a nezdržuje se v nich hmyz. Majitel ,ozdoby' musí držet hlavu vztyčenou a vrkoč, čnějící do výše a vznášející se nad krátkým tělem, podobá se žirafímu krku. Př́lišná tíže, spočívající na zadní části hlavy, způsobuje, že svaly na spáncích neobyčejně zdužní a spolu se svaly na krku a šíji vyhlížejí jako silné provazce“ (Holub 1973, 157).

Takové účesové „úly“ vyžadovaly hodně materiálu. Holub odhadl pořizovací cenu drdolu na hodnotu řádného vola. Výroba trvala týdny, snad i měsíce. Dílo řemeslníka, jenž zdobil ležícího muže, zaznamenal: „Švihácký vrkoč byl již do třetiny upraven. V pravé ruce držel vlásenkář silnou jehlu, asi takovou, jakých používají čalouníci. Do ní byla navlečena dlouhá nit z lýkových vláken. Vlásenkáŕ si pak svinoval z uchystaných vlasů copánky, zatáčel s nimi zároveň i nit a prošíval je navzájem. Byl-li některý copánek př́liš krátký, přikroutil k němu levicí nové vlasy... Kdo si účes neprohlédne zblízka, obyčejně vše pokládá za pravé vlasy. Aby dílo bylo řádně dokonáno, musí vlásenkář proplétání provádět se značnou silou, takže při každém zatáhnutí nejen hlava domorodce, ale mnohdy i celé tělo sebou škube“ (Holub 1973, 157).

\section{NEJDRAMATIČTĚJŠÍ ÚČESY AFRIKY}

Roztodivné účesy patřily v Africe ke svatbě, iniciaci, ale i k př́pravám na válku. Turkanové trávili hodiny úpravami, aby ukázali, že prošli zkouškami dospělosti. Zvláštní sestřih mívaly vdané ženy. „Fulbské ženy, proslulé v západní Africe svou krásou, nosí neobyčejně složité účesy, které lze přirovnat k sochařským dílům“ (Laude 1973, 39). Vznešené Fulbky v Ghaně si na obroučce navinuté vlasy zdobily korálky, penízky a řetízky. Dospělé ženy v Namibii si - ve čtyřicátých letech 20. století - obzvláště složitě splétaly copánky (obr. 12). Dámy Mangbetů $\mathrm{z}$ někdejšího Zairu prosluly trychtýřovitými účesy na zploštované hlavě, $\mathrm{v}$ čemž český afrikanista a sochař František V. Foit, který řadu domorodců také portrétoval, viděl značný estetický smysl: „Jejich vlasy tvoří centimetr silnou stěnu, velmi tvrdou, a jsou spresovány $\mathrm{v}$ jakousi obrácenou vázu na hlavě. Vypadá to velmi krásně a protaženou hlavu to ještě prodlužuje“ (cit. dle Klíma \& Kubica 1983, 103).

Kreace Mangbetů jsou asi nejslavnějšími účesy Afriky. Jak ženské koše, tak vysoké mužské „čepice“ fascinovaly již rané cestovatele. Roku 1870 se s nimi seznámil Schweinfurth, jenž pobyl u krále Mbunzy. Dílo Im Herzen von Afrika (1874) zajistilo účesům nehynoucí slávu, nebot je Schweinfurth barvitě popsal a přinesl i náčrtky čupřin - třeba králova syna Bunsy (obr. 13). Šlo o statusové symboly. Co ale trápilo antropology, byla zmínka o vpletených blondatých vlasech na princově hlavě, jež údajně tvořily až pětinu vysokého účesu.

Sám autor spekuloval o dědicově částečném albinismu, další

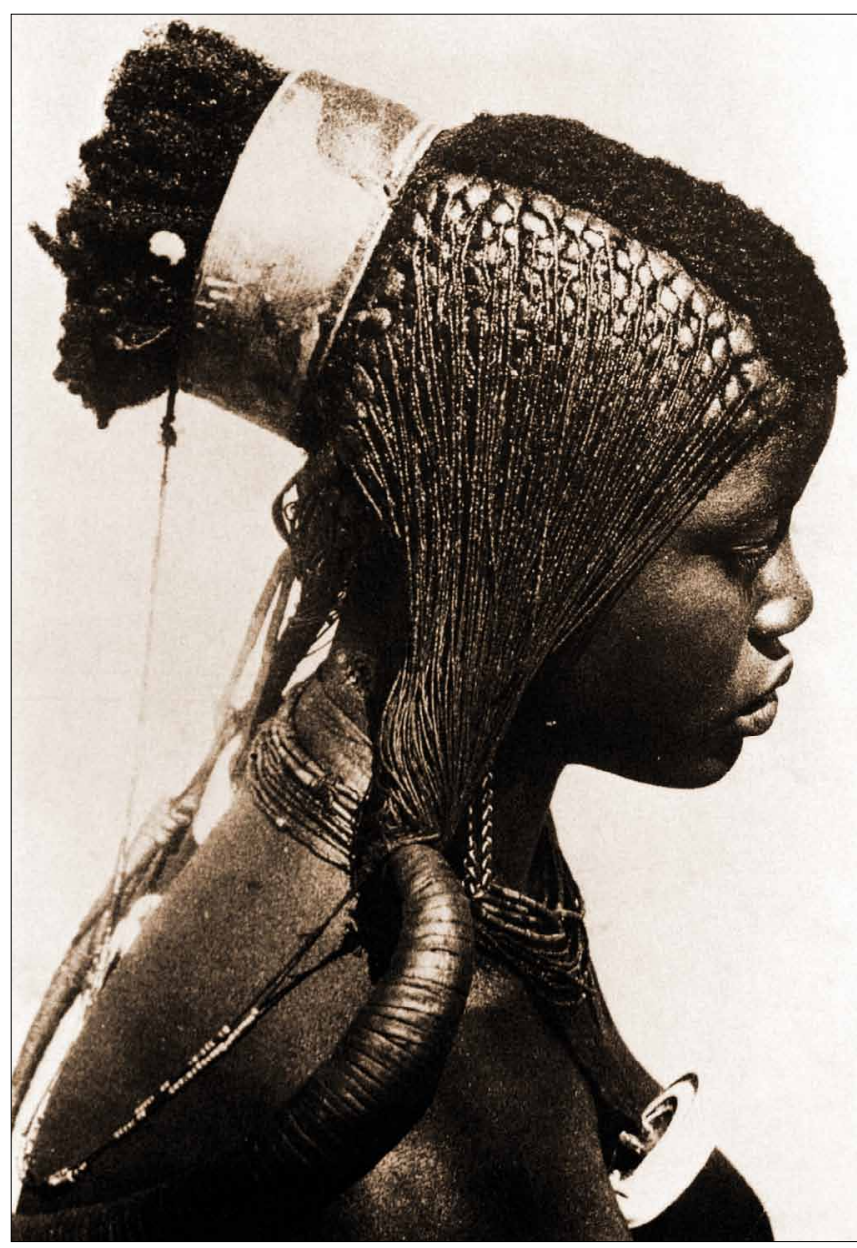

Obr. 12. Účes dospělé ženy. Skupina Wambo (Kwaluudhi, Ngandjera), Namibie. Asi čtyřicátá léta 20. století. (Foto: Annaliese Scherz).

pak o bělochům odňatých vlasech; dominikán M. H. Lelong mluvil o odbarvování, poněvadž jiní misionáři prý viděli Mangbety s hnědými vlasy, ale uspokojivé vysvětlení se najít nepodařilo. Dle Junckera (1882), jenž si povšiml uměle navozené dlouholebosti u dětí, vydržely tyto vázy na hlavě několik týdnů. „Jejich vlasy jsou předmětem puntičkářské péče; jsou česány, natáčeny a aranžovány tisícerými způsoby vždy ale vedoucími k dozadu vytrčenému cylindru, “ napsal si Gaetano Casati v roce 1892 (cit. dle Sieber \& Herreman 2000, 119).

$\mathrm{V}$ následujících letech již byli Mangbetuové, kteří vyráběli džbány s takto učesanými hlavami (jsou v Musée de l'Homme), fotografováni. Jedním z fotografujících byl belgický důstojník Hutereau, jenž byl vyslán do oblastí Uele a Ubangi spolu s vědci; nejslavnější fotku dámy s „dlouhou hlavou“ však pořídil tým zoologa Herberta Langa.

Původní košíkovitý účes se v 20. století změnil v častější trychtýř (obr. 14). Účes musel být nastavován cizími vlasy, jež se vplétaly do konstrukce $\mathrm{z}$ rákosu a pro lepší vzhled se látkou ovinovala i hlava. Dlouhá paráda se zdobila jehlicemi ze slonoviny, dřeva či mědi, jimiž se vyháněly blechy. Pouhá oprava „vázy“ trvala dle Laplumeho přes dvě hodiny. Pro 


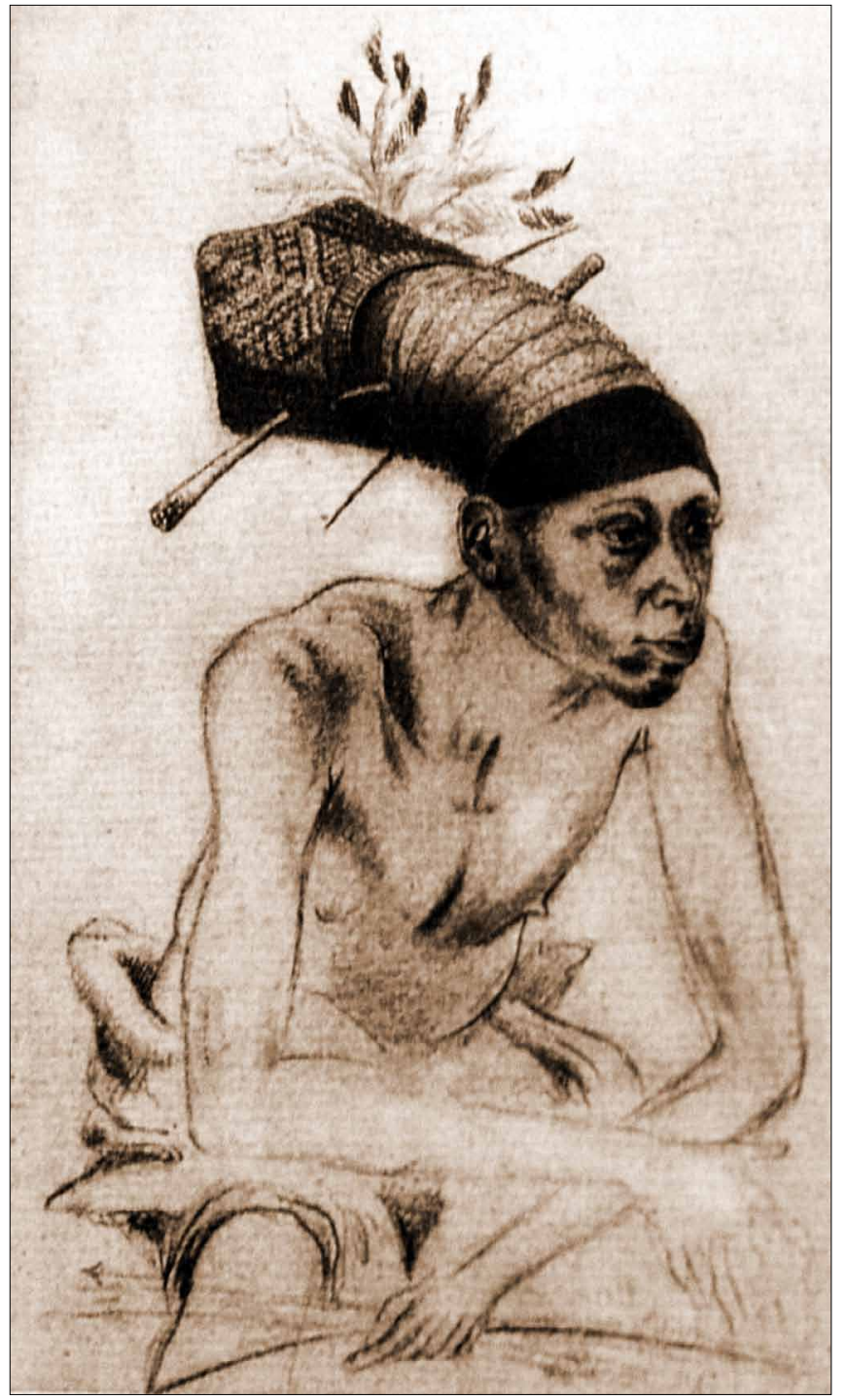

Obr. 13. „Bunsa, syn Munsy“. Syn krále Mangbetů s pletenou „čepici“" upevněnou jehlicemi k účesu. Rok 1870. (Kresba: George Schweinfurth).

zvýšení lesku se vlasy mastily olejem. Propaganda belgického Konga líčila Mangbety jako ideální „dolichocefaliky“ a roku 1931 se načesaný pár dostal i na poštovní známky. Zmínku zasluhují též ženy Zande (obr. 15), jež mívaly v týle „tác“ podobný načepýřenému pávovi (Fisher 1984 aj.).

Aby se takové účesy neponičily, užívají Afričané až dosud podhlavníků, stoliček ze dřeva, jimiž si ve spánku podkládají hlavu. Mívá i svou symboliku. Nevěsta, jež opouští domov a jde za manželem, mu v jižní Africe přinášela podhlavník, s nímž muž spojil život. Někdy se dřevěné „polštářky“ se zemřelými i pohřbívaly. Vyráběly se v různých verzích, existovaly i menší varianty, jakési podkrčníky, stoličky s jedinou anebo mnoha nožkami. Unikátem je podhlavník Nguniů, který je doplněn o dlouhou tyč, nebot na cestách sloužil majiteli dvojím způsobem: byl jednak opěrnou holí, ale při položení na zem i odpočívadlem (Mattet 2007, Sieber \& Herreman 2000, Heroldová-Štovíčková \& Herold 1994, Kandert 1984 aj.).

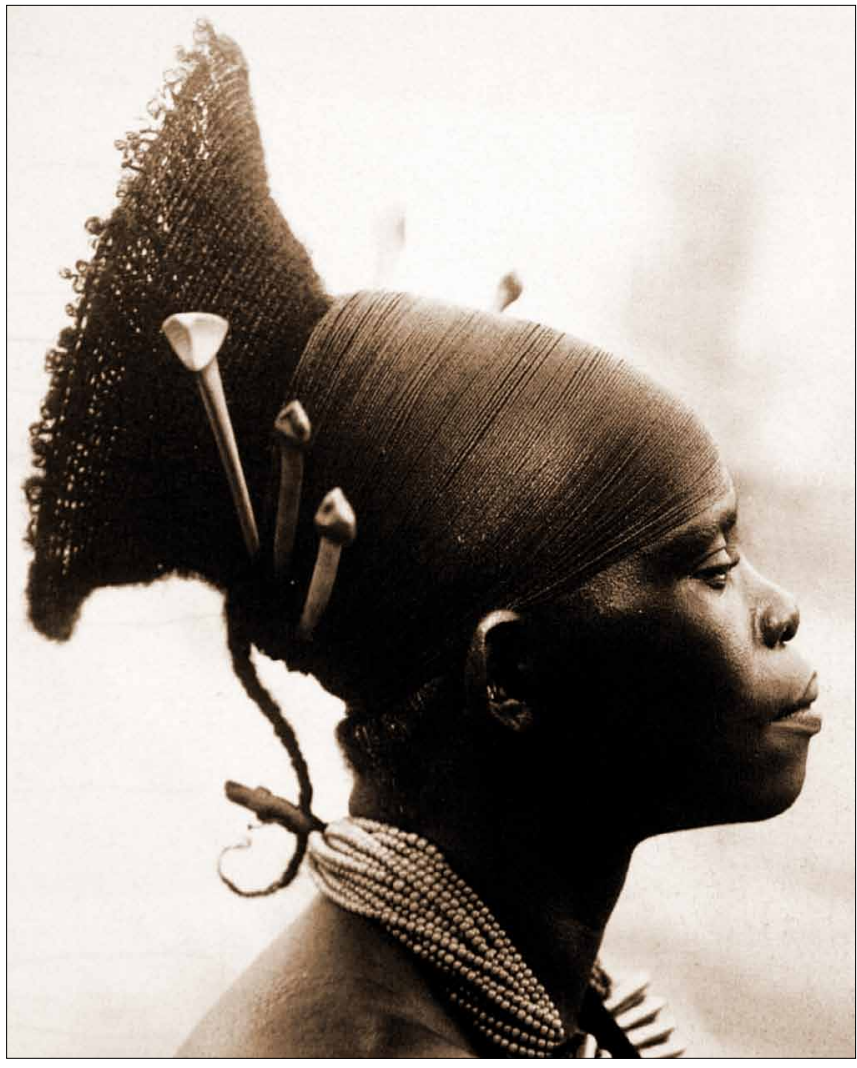

Obr. 14. Manželka etnika Makere (Mangbetu), konžská oblast Uele. Někdy mezi roky 1909-1915. (Foto: expedice Herberta Langa).

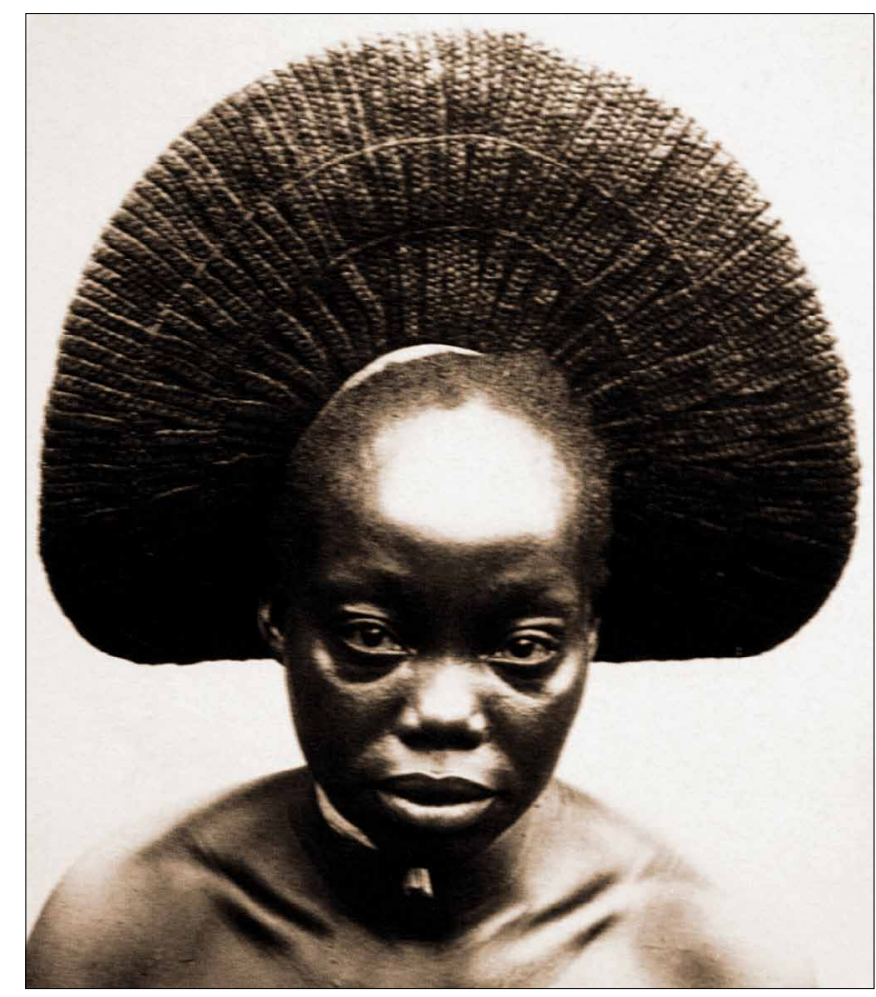

Obr. 15 - Paní Nasara, jedna z manželek Akengeho u Zandů (dnešní Demokratická republika Kongo) s typickým talírovitým účesem. Někdy mezi roky 1909-1915. (Foto: expedice Herberta Langa). 


\section{ZAKOUZLENÉ VLASY A SYMBOLY}

Ústřední roli hrály vlasy v magii. Docházelo tím ke spojení se silami, které mohly pomáhat nebo škodit (Rychlík 2013a, Sherrow 2006, van Gennep 1997, Frazer 1994, Leach 1958). $\mathrm{Na}$ jedné straně vlasy značily sexualitu, plodnost a vitalitu, na druhé straně patřily i ke smrti a nemocem. Etnika Yaka, Yanzi a bantuští Teke měla figurky mpungu, do nichž se odkládaly odejmuté kadeře nemocného, aby se zlepšil jeho stav. „Medicinmani $\mathrm{v}$ Kamerunu připevňovali prameny vlasů ke skř́ńnkám, kde byly umístěny jejich léčivé lektvary, aby byly přípravky chráněny a zvýšila se jejich účinnost" (Sherrow 2006, 13).

U Jorubů se sedm až devět dní po narození dítěte konaly postřižiny a oholení vlásků značilo pro nemluvně přechod z říše duchů do světa živých. Jorubským dvojčatům (ibedži) a hodně ovlaseným novorozencům (dada) byly vlásky kráceny během obřadu, přičemž bohatost porostu symbolizovala prosperitu, jíž rodičům přinesou. Vlasy se dávaly i do amuletů.

Ale patřily i ke smutnějším údělům. Už Loyer (1701) popisuje na Pobřeží slonoviny zvyk učesat nebožtíka. Akanové z Ghany holili zemřelému hlavu před pohřbem, což bylo úkolem příbuzných. To se týkalo mnoha národů včetně Zulů, zvláště v případě úmrtí náčelníka. „Nejprve se upraví tělo zemřelého. Obřadně se umyje obličej, oholí hlava (vlasy se schovají a spálí spolu s tělem) a mrtvý bude posazen, s koleny složenými pod bradou. To vše se uskuteční pod dohledem nového náčelníka, nejstaršího syna zemřelého“" (Lawson 1998, 46).

Pakliže dotyčný skonal daleko od domova a tělo nemohlo být odvezeno, bývalo zvykem odstřihnout mrtvému pár kučer a dát je do skř́ńnky. Ta pak „byla místo rakve zakopána v domovské půdě zemřelého" (Sieber \& Herreman 2000, 26). Etnika Bwende a Beembe vyráběla v upomínku na předky postavičky, jež obsahovaly kousky jejich nehtů a vlasů. Pozůstalé

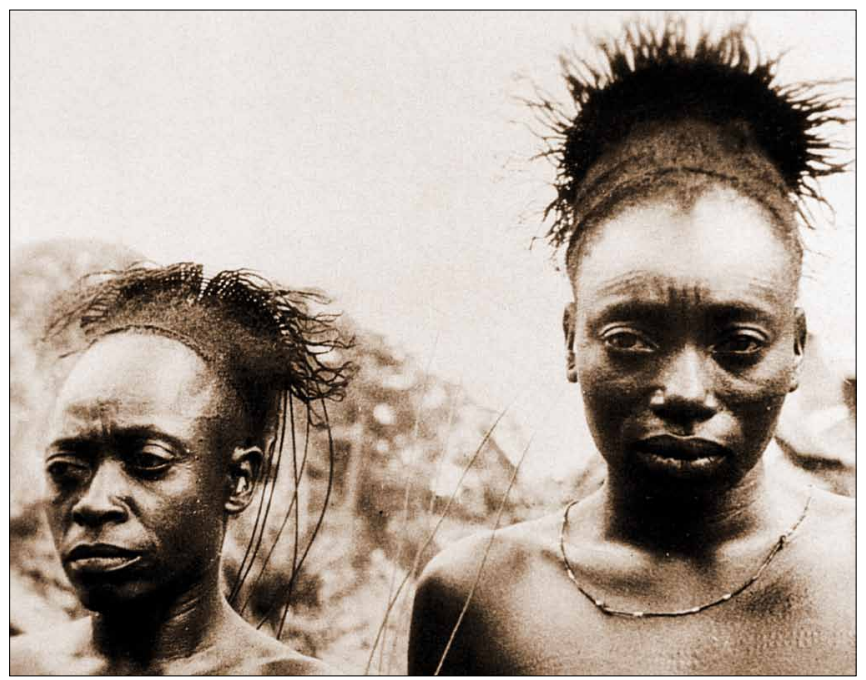

Obr. 16. Poničené účesy vdov u Mangbetů z konžské oblasti Uele. Rok 1945. (Foto: R. F. Marcolin).

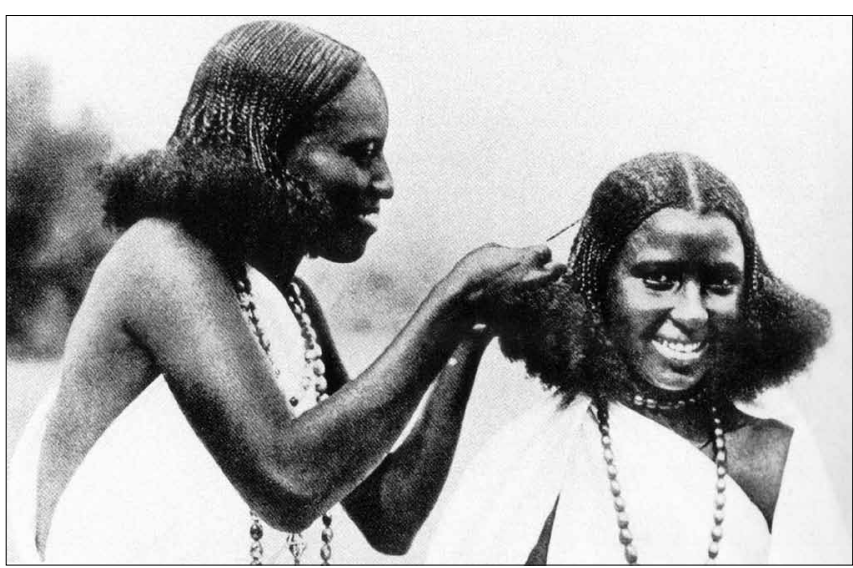

Obr. 17. Vzájemné česání, východní Afrika. Nedatováno. (Foto: archiv).

Afričanky si stř́ihávaly vlasy; Malgašky se musely oholit, ale některé vdovy si vlasy uschovaly, aby $\mathrm{z}$ nich vyrobily paruky, jež nosily po skončení doby smutku. Vdovy Mangbetů si musely poničit své nádherné trychtýře, $\mathrm{z}$ nichž pak trčely jen smutné svazky vlasů (obr. 16).

Málokdy se etnografové přesně zmiňují, co se s ostř́íhanými kadeřemi dělo. Bagatelizují jejich další osud slovy jako zničeny, spáleny, zakopány... Koncem 19. století se R. Austin Freeman dostal do ghanského města Nsoko. Při obhlídce si povšiml mohyl, mezi jejichž spárami byly - bez jakýchkoliv pochyb - nastř́íhané vlasy. Aby záhadě přišel na kloub, ptal se místních, kteří mu vysvětlili, že na ta místa odnášejí sbírané odstřižky, které ukládají pod kouzelné kameny. Ty měly zabránit zneužití vlasů k čarodějnictví. Jiné zdroje se zmiňují o existenci bronzových popelnic na vlasy; ještě roku 1967 je tam viděl Sieber. Byly plné, nebot právě zemřela „královna matka“ a truchlící přinášely kučeravé obětiny (Sieber \& Herreman 2000).

Další zvyk, jak s vlasy nakládali ghanští Ašanti, uvádí „ašantolog“ Robert S. Rattray, když píše roku 1927 o dějích, jež následovaly po úmrtí v rodině. „Všichni pokrevně spříznění zemřelého si holili hlavy; vlasy se vkládaly do hrnce. Při svítání některé $\mathrm{z}$ žen klanu vzaly veškeré nádobí... a jídlo, a ,rodinný kotlík' s kadeřemi... a směřovaly, jdouce velmi opatrně a bez ohlížení, $\mathrm{k}$,houštině duchů', tj. pohřebišti, kde věci položily, nikoliv však na hrob, ale v části hřbitova nazvaného asensie, na ,místo kotlů'. Tam rozmístily varné kameny, hrnce daly na ně... a vedle uložily ,rodinný kotlík'; v tutéž chvíli pravily: Zde je jídlo. Zde jsou vlasy $\mathrm{z}$ našich hlav. Přijmi je a jdi a hlídej je pro nás... Ukončily jsme tvé pohřební obřady. Zavřely jsme cestu. Jest to skončeno“ (cit. dle Rattray 1927, 164-165). A vrátily se tam, kde je čekali vesničané.

V Ghaně se vlasů mohlo dokonce užívat jako platidla v zásvětí. Tvrdila to Eva L. R. Meyerowitzová, která napsala knihu o státu Akanů. Když král omanhene zemřel, všichni obyvatelé města se museli v poslední den pohřebních obřadů ostř́íhat a oholit po celém těle. Vlasy příbuzných z královské linie se daly do předmětů s jeho podobiznou a umístily na hrob. „Kadeře dotyčných byly zavinuty do listí a uschovány u hrobu. 


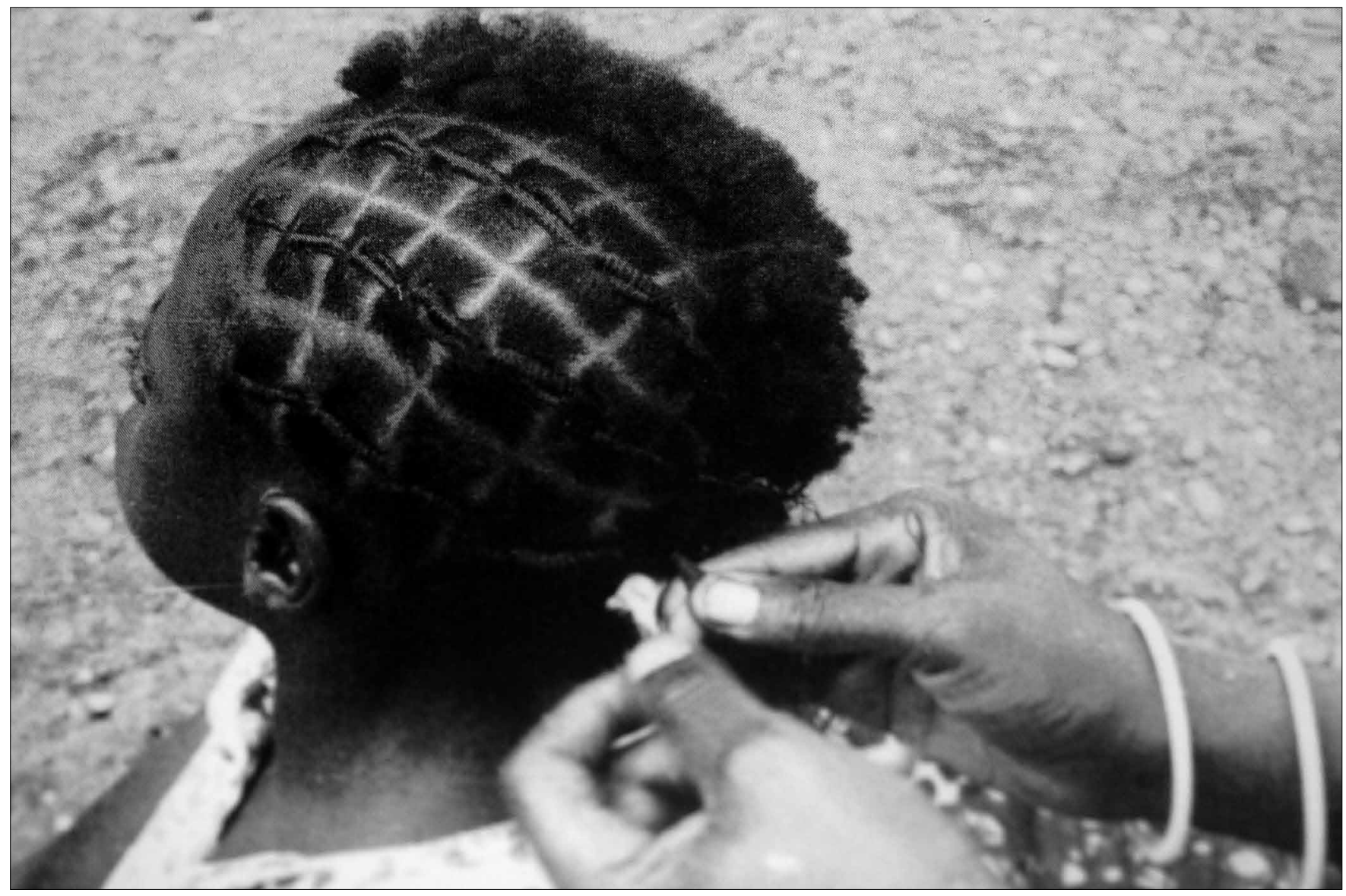

Obr. 18. Splétání účesu, západní Afrika. Nedatováno. (Foto: Afrika Museum, Berg en Dal).

Trvanlivé vlasy jsou považovány za peníze; pojem užívaný pro peníze je sika (zlato), což je věčné a má dle akanské víry oživující účinky. Proto jsou vlasy rovny zrození života a mohou zemřelému dát ,život ' v sumandow, v podsvětí, kde nelze platit opravdovým zlatem“ (Meyerowitz 1952, 47).

Nepěstěné vlasy byly obecně považovány za znak nemoci, smutku nebo vyšinutosti. M. D. McLeod píše, že u Ašantů měli kněží zacuchané lokny ve stylu mpesempese, což se dá přeložit jako „tohle nemám rád“ (McLeod 1981, 64). Nestříhané vlasy mívali i blázni a kati.

Pravidelná péče o kadeře byla záležitostí těch nejbližších, přátel nebo př́buzných (obr. 17), teprve později vznikli specialisté. Ke stř́ihání patřila důvěra. Afričtí kadeřníci mívali ve společnosti dobrý status: jednak zacházeli s „kouzelnými“ vlasy, ale také si s klienty vyměňovali klípky. Třeba „v Ghaně a Senegalu se kadeřníci mohli věnovat pouze lidem téhož pohlaví (Sherrow 2006, 13). U Langů z Ugandy, kteří zavedli i povinný účes atoro pro dvojčata, se dle Driberga za jedno sezení, jež trvalo několik hodin, platilo džbánem piva a kuřetem. Holiči a kadeřníci měli na starost rozčesávání, pletení copánků, tvarování a olejování (obr. 18). Asi nejoblíbenější pomůckou byl palmový olej, ale směsí tuků a hlinky byla přehršel. Obyvatelé Madagaskaru, Malgaši, používali po staletí tužidlo tavo, což byla kombinace medu a sádla.

\section{HŘEBENY, JEHLY A JINÉ NÁSTROJE}

Nejběžnějším náčiním k úpravě byl také v Africe hřeben (obr. 19). „Češou se dřevěnými neb kostěnými vidličkami se čtverem zubů, jež jsou vždy vpleteny v jejich hlavy, " psal Loyer v roce 1701 (cit. dle Sieber \& Herreman 2000, 125). Vlasy se nakadeřily, nadzdvihly, a pak se z nich utvářely copánky nebo rozličné tvary. Voněly se. A to levandulí, santalovým dřevem či kadidlem. Do vlasů se vplétaly korálky, mušle kaurí, kousky textilu, slonovina, stužky, květiny, knoflíky, pera, plíšky kovů, později i šroubky a nábojnice (u Zembů), zkrátka vše, co bylo barevné, lesklé, a mohlo se hodit (Sherrow 2006, Sieber \& Herreman 2000 aj.).

Krásnými jehlami do vlasů prosluli tanzánští Kwereové; nigerijští Ibové vyráběli pěkně vyřezávané hřebeny. Dlouhé hřebínky s lidskými portréty, ale i se zlacenými držáky měli Bauleové z Pobřeží slonoviny, do jejichž folklóru se dostal př́iběh o princezně Maji, která se nikdy nesměla dotknout hřebenu. Když se to dozvěděla zlá bába, „vytáhla hřeben ze svého účesu a zarazila jej děvčeti do vlasů. V tu chvíli se Maji změnila v překrásného ptáka“ (Heroldová-Štovíčková \& Herold 1994, 37). Ale její snoubenec Kofi ji poznal podle jejího zpěvu, hřeben z peří vypadl a byla svatba.

$\mathrm{V}$ Keni se vytvářely kovové hřebeny, $\mathrm{v}$ Zairu kusy $\mathrm{z}$ drátem 


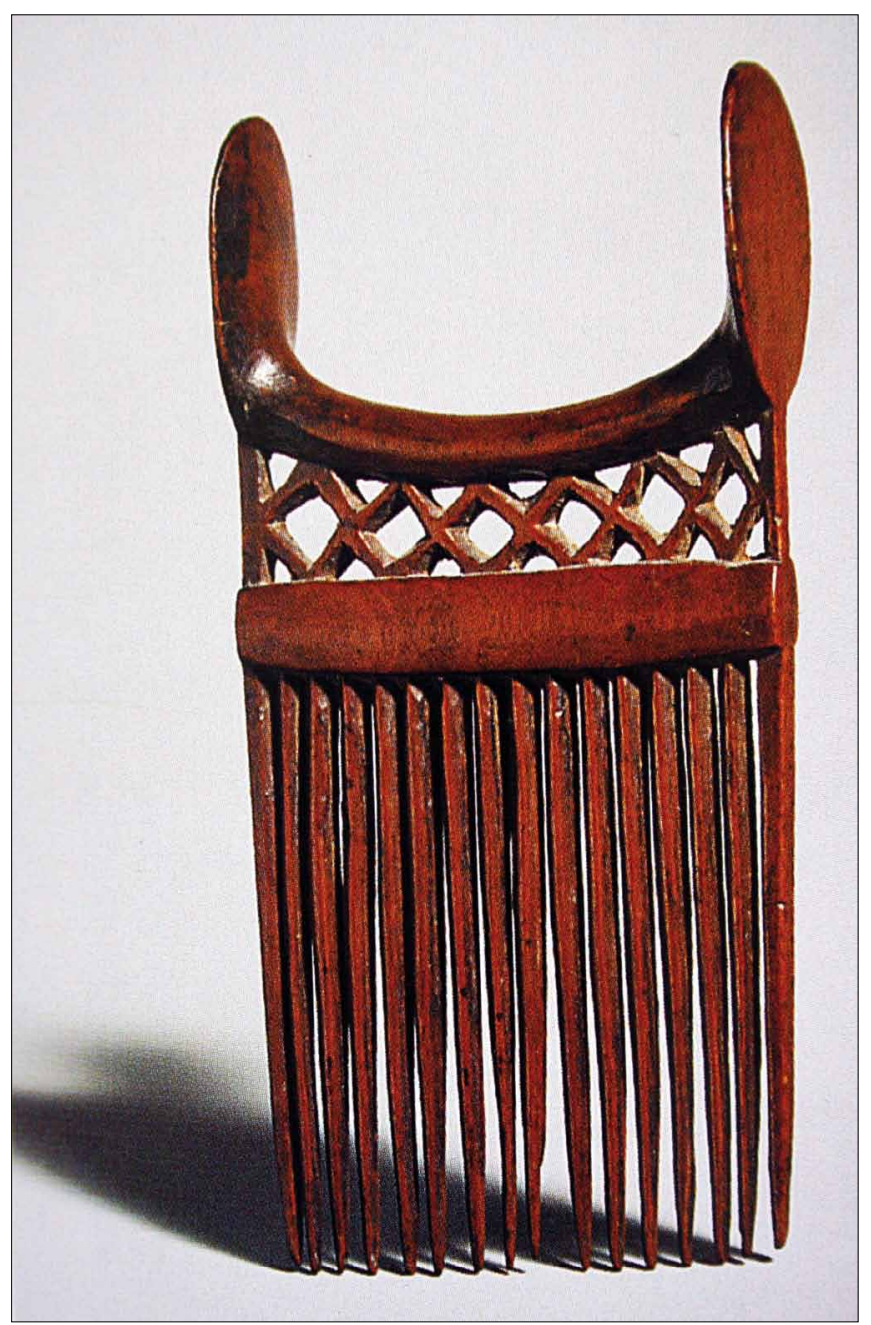

Obr. 19. Dřevěný hřeben z východní Afriky, výška $13 \mathrm{~cm}$, nedatováno. Soukromá kolekce. (Foto: dle Sieber \& Herreman 2000, 126).

svázaného rákosu. Čokvové vyřezávali dřevěné hřebínky pro vlastní potřebu i na obdarování přátel. Zajímavé byly oboustranné trojjehlice zairských etnik Kaniok, Yaka či Suku. Jehlice Zulů měly tř̌i hroty, ale v horní části byly doplněny nádobkou, v níž se v účesu nosil zastrčený šňupací tabák. Podobně sloužily Zulům slonovinové hřebínky s vyhloubenými lžičkovitými žlábky. U Ašantů (skupina Akanů) hřebeny původně vyráběli vandrovní řezbáři, později se díla ujali mladí muži, kteří je vyřezávali pro matku nebo svou vyvolenou. Výrobky měřily na výšku až 35 centimetrů: „Hřeben měla každá žena, at $\mathrm{z}$ rodu královského či otrokyně, a některé jich mají hned několik; podle toho, jak se líbí a kolik mladých mužů se o ně uchází. Hřeben má nejméně sedm zubů, nebot’ sedmička je posvátné číslo akanských rituálů. Rukojet’ hřebene zdobí figurka zvířete, výjev ze života či ilustrace známého prríslovi“ (Heroldová-Štovíčková \& Herold 1994, 43).

Tam, kde se málo česalo, pomohly hmoty. U pasteveckých Nuerů v Súdánu, o jejichž kultuře prohlásil E. E. Evans-Pritchard „Za vším hledej krávu“" (cherchez la vache), se vlasy upravovaly jedinečným způsobem. „Aby se vlasy obarvily, přesněji řečeno odbarvily, do červena a narovnaly, byly pokryty směsí z kravského trusu a moči a popela. Tato hmota zůstala na hlavě asi deset dní a čas od času se polévala kravskou močí. Potom byla ztvrdlá hmota sloupána, vlasy důkladně vykartáčovány a potřeny tukem“ (Jiroušková \& Todorovová 2003, 115). Podobný kondicionér, popelovou pastu, znali i sousední Dinkové. Samuel Baker, jenž projel Súdánem koncem 19. století, si o nich poznamenal: „Jsou v něčem nepřekonatelní. Muži jsou nazí tak, jak se rodí, svá těla pokrytá prachem a s vlasy obarvenými do červena dík štuku z popela a kravské moči. Tito lidé jsou nejvíce nadpozemsky vypadajícími dábly, jaké jsem kdy viděl“ (cit. dle Fisher 1984, 61). Estetický účinek byl v Africe obzvláště mocný; což je samostatné a velké téma pro etnoestetiku.

\section{ÚČESY V UMĚNÍ, UMĚNÍ VE VLASECH}

Kromě odborné literatury, fotografií či jiných materiálů z oblasti vizuální antropologie máme jakožto etnologové pro poznání dějin účesu $\mathrm{v}$ Africe navíc i skvělou pomůcku africkou plastiku a nativní umění obecně, ač jde v př́ípadě tohoto pojmu o etnocentricky konceptualizovaný termín, který má řadu mimoestetických funkcí (Rychlík 2012, Mattet 2007, Kandert 1984, Laude 1973 aj.). Pakliže jsme ale ochotni považovat řadu kultovních předmětů za formu „umění, naskýtá se i otázka, jestliže by vedle vyřezávaných zbraní, masek, nahrávek hudby či hřebenů, jež se objevují v muzejních sbírkách coby „umění, neměly figurovat i doklady popsaných účesů - vytvářených s nepopiratelným umem.

„Navzdory zmínkám o abstraktním charakteru afrického sochařství existují dvě oblasti ze skutečného světa, jež jsou takřka bez výjimky zobrazeny přesně, pochopitelně však umělecky: skarifikace a účesy. Obojí slouží k rozpoznání etnické identity, původu, pohlaví, životních fází, statusu, stejně jako osobního vkusu. Je třeba zdůraznit, že veškeré kadeřnictví Afriky má značný estetický obsah“ (Sieber \& Herreman 2000, 15).

Odraz účesové tvorby je v africkém umění (obr. 20), jež se za-

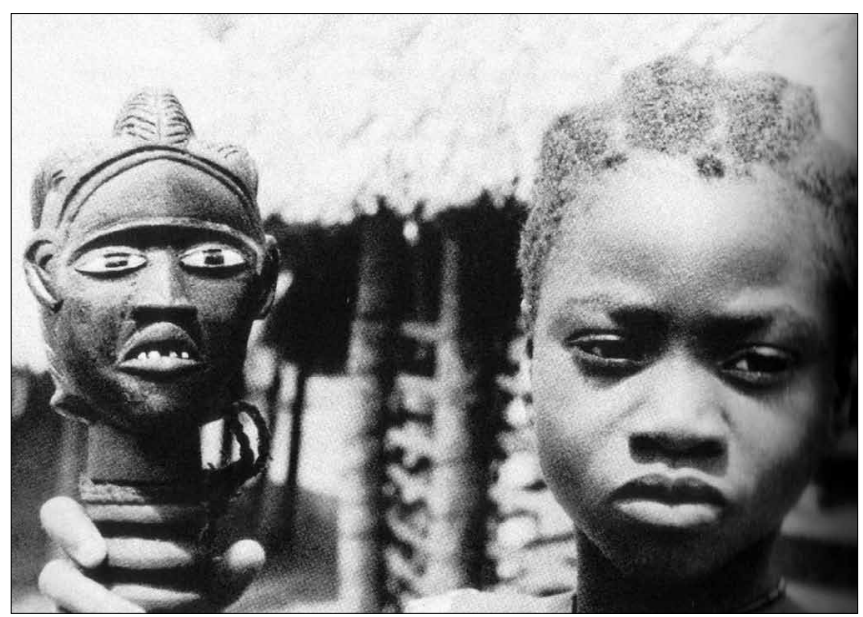

Obr. 20. Účesy se často odrážejí i v africkém umění. Bez datace. (Foto: Frank Willet). 


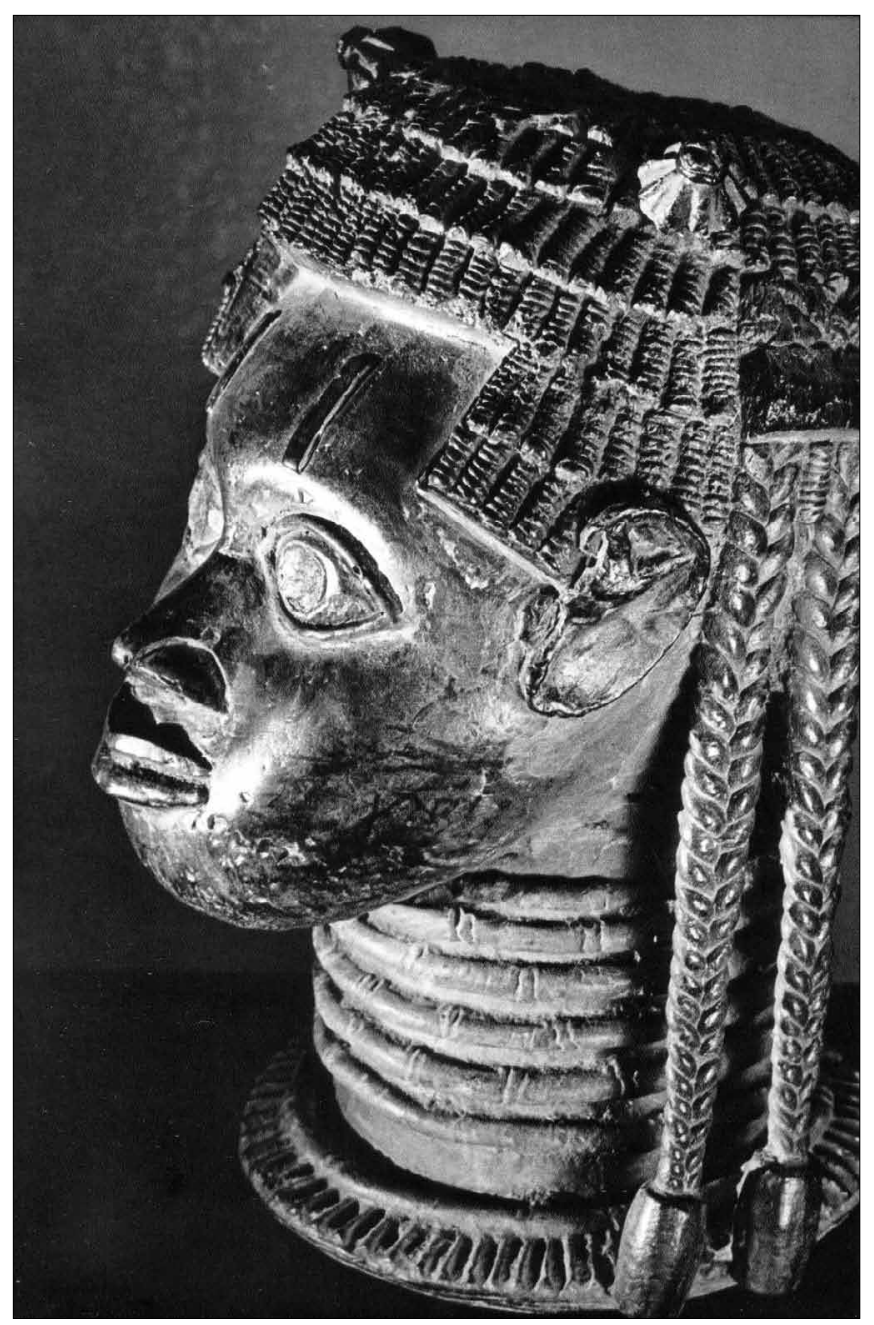

Obr. 21. Bronzová hlava z Beninu se složitými copánky. Výška $22 \mathrm{~cm}$, asi 17. století. Univerzitní muzeum v Cambridge. (Foto: W. a B. Formanovi).

obírá především tělem, častý (Laude 1973). „Oči, uši nebo nos přeformuloval africký řezbář do geometrických tvarů, zato účesy, umělé zjizvení na tvárích či na čele přenesl na figuru s naturalistickou přesnosti“ (Heroldová-Štovíčková \& Herold 1994, 129). Stačí zmínit postavy Lubů a Baulů s copy a číry, malgašské sochy s „ježíky“, kohoutí hřebínky Bembů či postavy s drdoly u kmene Guro a pásovité vlny Ašantů. Beninské bronzy ze 17. století - zvláště hlava s copánky z muzea v Cambridge (obr. 21) - ukazují pak dvorský styl účesů. I na pohárech Kubů byly obličeje s chocholy, ale zvláštní pozornost zasluhují africké masky (Rychlík 2012).

Masky od Ejaghamů (Ekoi) z Nigérie měly hadovité účesy upomínající na Medúsu, nebot i jí vlasoví „hadi“ trčely z lebky. Nádherný exemplář dlí ve sbírkách ženevského Musée Barbier-Mueller (obr. 22). „Monumentální účes sestává z pěti stočených pletenců, $\mathrm{v}$ africkém sochařství neobvykle velikých a provedených $\mathrm{k}$ dokonalosti a symetrii copů. Etnografické záznamy uvádějí, že takový účes nosily mladé dívky při iniciacích. Svazky byly podepřeny výztuží a uhněteny jílem, který držel vlasům a přidaným loknám tvar“ (Mattet 2007, 174). Jde sice o uměleckou licenci, ale skutečné pravzory tohoto „účesu" lze dle afrikanisty Herremana nalézt a doložit.

I hřebínky na maskách Igbů mají reálný základ. Makondové z Tanzánie, kteří realisticky ztvárňovali obličejové jizvení a účesy, doplňovali plastiky lidskými vlasy. Stejnou ozdobu mají nástavcové masky Ekojů a Ibů v Kamerunu, Keaků či Ejaghamů (obr. 23); Wobe-Beteové přidávali maskám i opravdické vousy. Bohaté „účesy“ $\mathrm{z}$ rostlinných vláken měly masky angolských etnik Čokve nebo Lwena (Kandert 1984, Laude 1973 aj.).

Ale jen máloco z „vlasatého“ umění se vyrovná maskám sowei, jež užívaly ženské společnosti Sande v Libérii a Sierra Leone. Masky sloužily v iniciačních školách jako zosobnění zdraví a sil, ale reprezentovaly též ideál ženské krásy u etnik Mende, Bullom-Šerbro, Temne, Vai, Gola nebo Bassa. Podle Booneové se tam vlasy pojily jak fyzicky, tak metafyzicky s ženskou krásou. Kučery „měly být čisté, lesklé, dobře pěstěné a pěkně řasené. Pouze černá barva byla vhodná, hnědavé odstíny byly

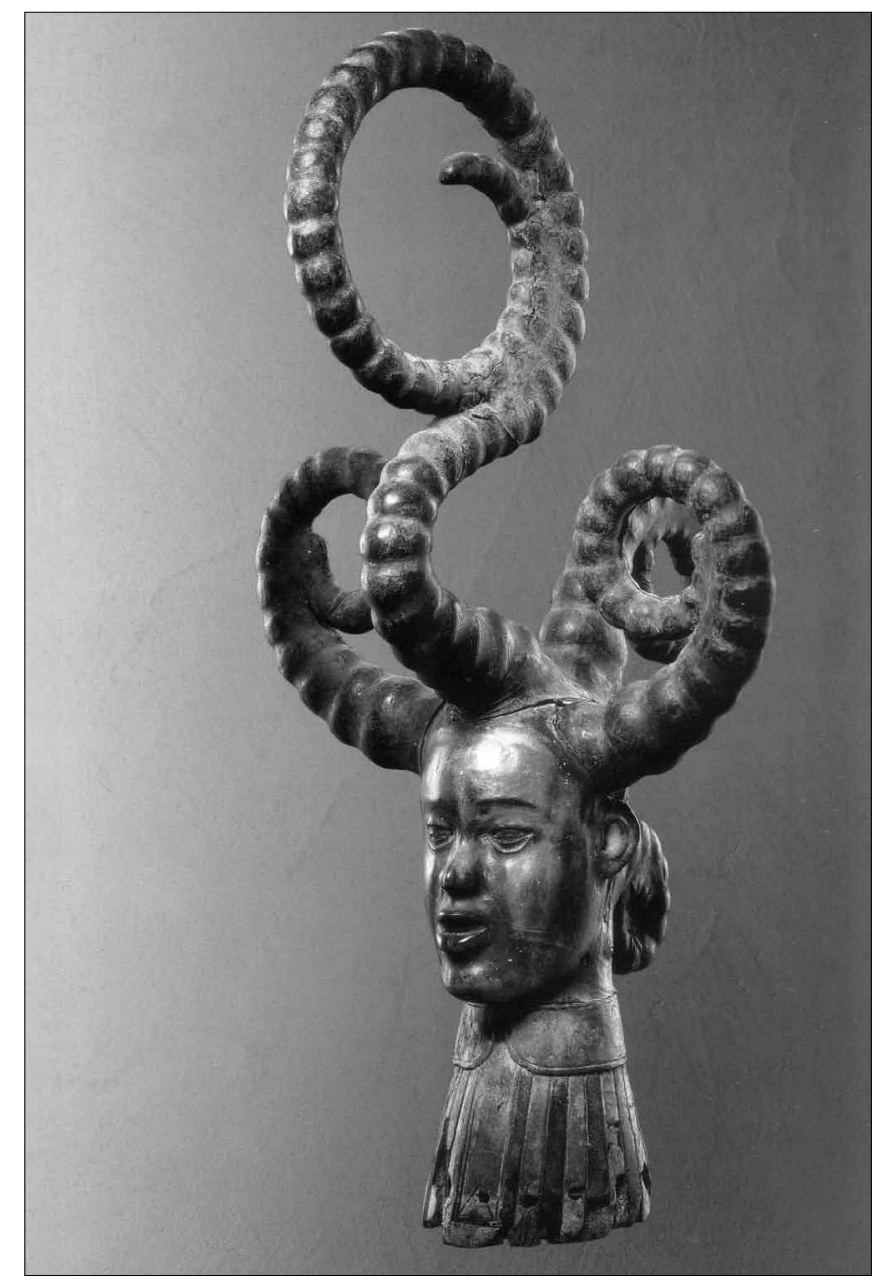

Obr. 22. Hlavový nástavec. Patrně Ejaghamové/Ekoi, oblast Cross River, Nigérie. Jistě skromnější, ale podobně vyvedený účes nosily dle etnografických záznamů mladé ženy během iniciace a před vstupem do manželství; vlasy byly modelovány jílem. Výška $72 \mathrm{~cm}$, přelom 19. a 20. století. Ze sbírek ženevského muzea Barbiere-Mueller. (Foto: Musée Barbier-Mueller, dle Mattet 2007, 175) 


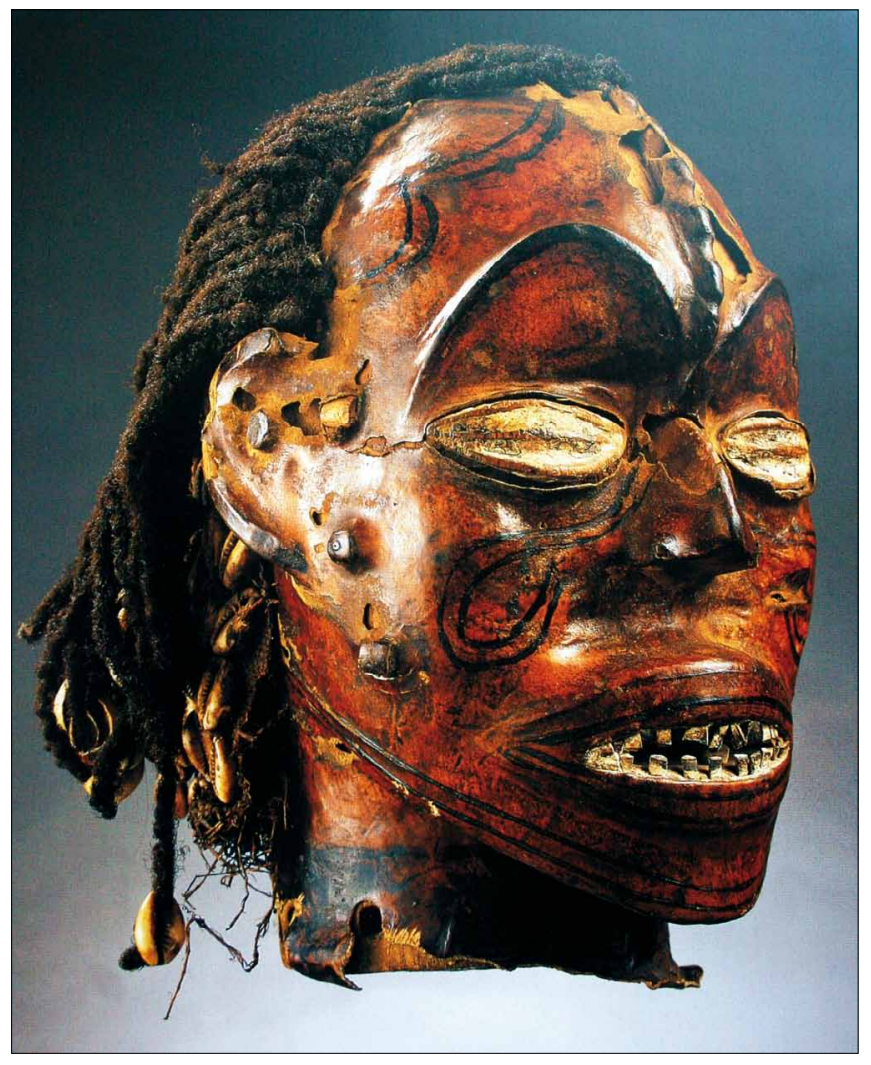

Obr. 23. Maska. Ejaghmové, Nigérie. Materiály: dřevo, kůže, vlasy, mušle kauri. Výška $26 \mathrm{~cm}$. (Foto: Rolf a Christina Miehler, dle Sieber \& Herreman 2000, 57).

považovány za špínu“ (Boone 1986, 96). Ve filosofické rovině byly kadeře spjaty s vegetací - obojí rostlo; hlava měla být podobna pěstěnému políčku. Dozadu se sbíhající brázdy vlasů byly prý odevzdáním se společnosti, nebot žena si takový účes nemohla vytvořit sama. Nejběžnější brázdovité účesy se pak také skutečně objevují na maskách sowei (Mattet 2007, Sieber \& Herreman 2000), které reprezentují tradice, rituály, společnost i silný estetický účinek (Rychlík 2012).

\section{ZÁVĚR}

Afrika se měnila a mění, včetně účesů. Zachytit trendy v tomto krátkém přehledu je zhola nemožné. Zasáhla nejen bílá civilizace (složité účesy byly tř̌eba Bena-Luluům zakázány spolu se skarifikací v roce 1880) či vliv islámu. Vždyt i s příchodem proroka Muhammada, který žil asi v letech 570 až 632, se mnohé změnilo. Islámských tradic, jež se vyjadřují $\mathrm{k}$ tomu, co má a nesmí muslim nosit či jak má vypadat účes a vous, je řada. Některé byly vyjádřením božích prríkazů, jiné odrazem Muhammadova vkusu. Sunna, soubor návodných činů Prorokových, ilustruje život tehdejší společnosti. Víme proto, že Muhammadovi současníci „dětem po úmrtí v rodině dělali punkerské účesy nebo že ženy se tetovaly, brousily si mezi předními zuby mezeru a vyráběly prríčesky" (Pelikán 1997, 141). Sunna pak vysloveně zakazuje „účes na kohouta“ a na jiném místě se pravověrní dočtou o postoji ke stárnoucím vlasům a vousům, jež si mohou dle Prorokova vzoru barvit; sám prý měl vous hennou začerveněný. I dnes muslimům - už na jižnějších místech Afriky - vadí různé účesy: třeba Fulanky (Fulbky) byly zvyklé si holit skráně, splétat na nich visící copánek a nad čelo si vyčesat mohutný kokrhel, což fulbští vyznavači Alláha „zesměšňují, nebot taková žena se nedokáže řádně modlit a dotknout se čelem země“ (Fisher 1984, 164).

Africké tradice se mění i pod vlivem módy a prchavých nálad; zde je interpretace zvláště složitá. Už ve čtyřicátých letech 20 . století patřil v Ghaně k nejoblíbenějším stylům sestřih na „Joe Louise“, slavného boxera (Sieber \& Herreman 2000). Roku 1976 vydal Titus Ogunwale knížku o účesech, v níž osvětlil řeč moderních nigerijských stylů. Konec občanské války prý Jorubky oslavily účesem gowon nazvaným podle hlavy státu. Na nový most v Lagosu reagovaly kreací „most Eko“. Novinky se kopírovaly ze žurnálů, letáčků, reklamních desek (obr. 24), a tak se i některé hity dostaly do USA či Karibiku...

„Další účesy se jmenovaly ananas, mrakodrap, autobus, košík, ale i sedící pes, koleno mrzáka nebo prasečí zátylek. Zatímco

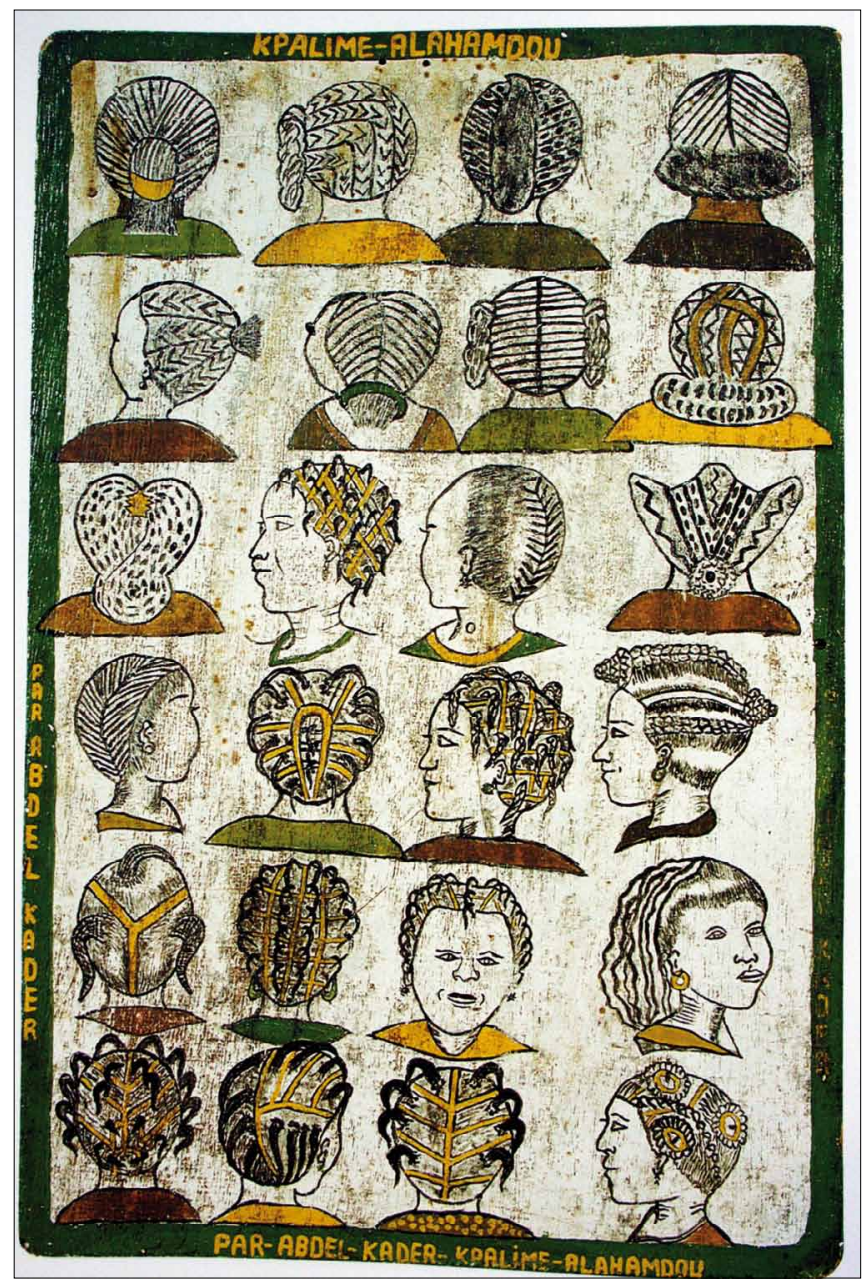

Obr. 24. Reklamní cedule na kadeřnictví, západní Afrika, konec 20. století. Malovaný dřevěný panel, výška $61 \mathrm{~cm}$. (Foto: Roy a Sophia Sieber; Sieber \& Herreman 2000, 170). 


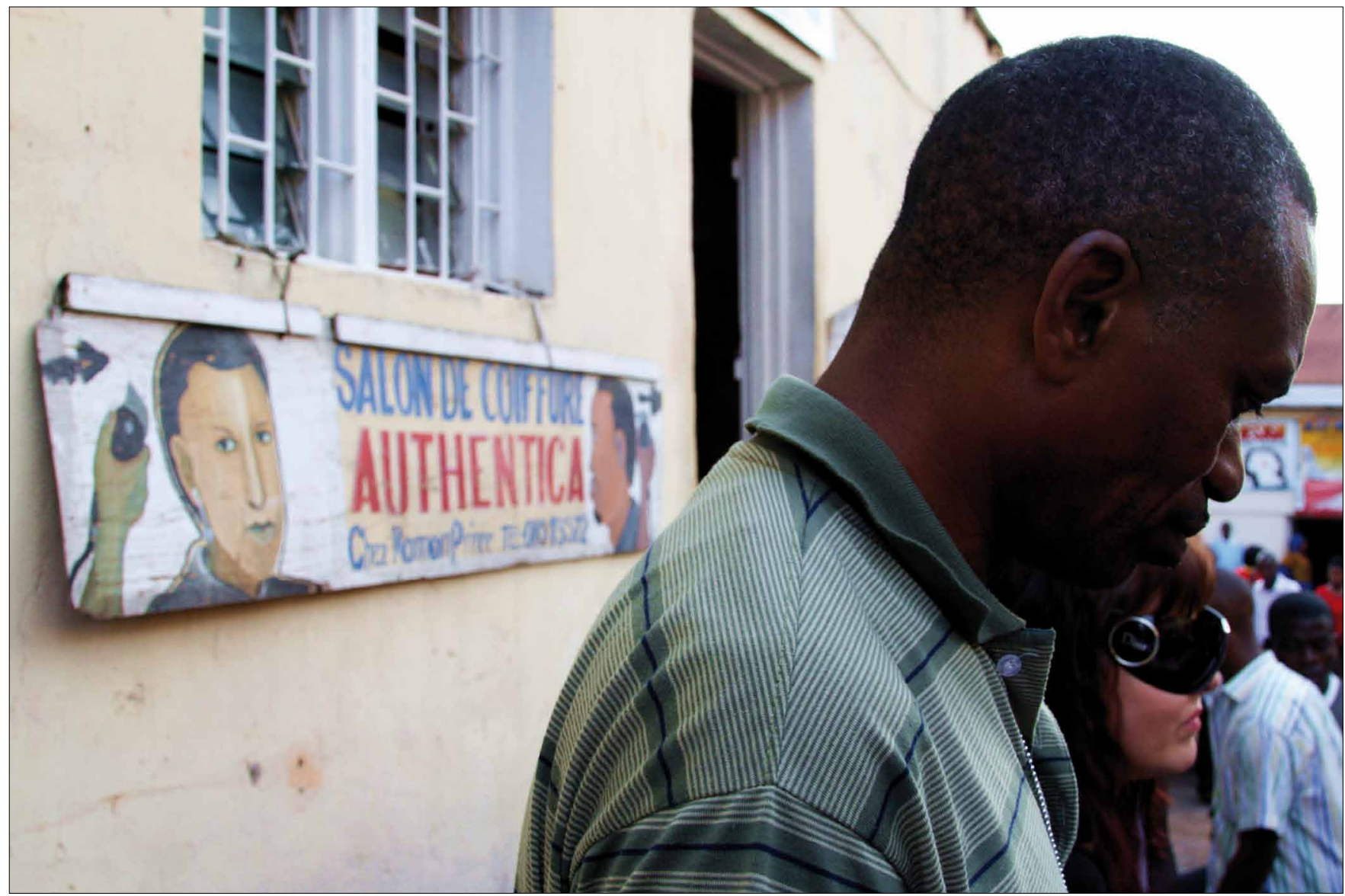

Obr. 25. Vstup do „autentického“ kadeřnictví v centru Kigali, v hlavním městě Rwandy. Rok 2009. (Foto: Martin Rychlík).

na běžných účesech Nigerijek rozlišujeme kolem deseti řad $\mathrm{z}$ vlasů, ženy z rodiny tradičního krále jich musely mít až šedesát. Název této vlasové úpravy byl charakteristický: ,oddíl pochodujících vojáků'“ (cit. dle Klíma, Kubica 1983, 103). A jakoby symbolicky s prechodem do moderny si jedna studentka z Mbandaky vyčesala v sedmdesátých letech 20. století účes ve tvaru kosmické sondy Sputnik.

Předmětná studie měla naznačit výjimečnou pestrost a barvitou historii afrických účesů (ve vazbě na sociální prostředí), o což by se s akcentem na nedávný vývoj mohly zajímat mnohé antropologické subdisciplíny, nicméně tak - bohužel - činí jen sporadicky. Z literatury sice můžeme usuzovat na odklon od společensky sdílené symboliky účesů k větší individualizaci a „sekularizaci“, nicméně data pro konkrétní etnika či země dodají jen terénní výzkumy. Ač jsem kupř́kladu v roce 2009 krátkodobě navštívil kadeřnictví ve Rwandě (obr. 25), tak ani na rozbor tamní situace si netroufám - jde o téma, jež bytostně náleží specializovaným afrikanistům, leč které zároveň dalece přesahuje finanční možnosti současné české vědy.

\section{LITERATURA}

Anger, S., \& Dieck, A. (1978): Skalpieren in Europa seit dem Neolithikum bis um 1767 Nach Chr. Materialsammlung. Bonner Hefte zur Vorgeschichte, 17, 153-240.
Axtell, J., \& Sturtevant, W. C. (1980): The Unkindest Cut, or Who Invented Scalping. The William and Mary Quarterly, 37 (3), 451-472.

Banek, K. (2010): Opowieść o włosach. Zwyczaje - rytualy - symbolika. Warszawa: Trio.

Battúta, ibn, Muhammad ibn Abdalláh (1961): Cesty po Africe, Asii a Evropè. Praha: SNKLU.

Berg, C. (1951): The Unconscious Significance of Hair. London: Allen \& Unwin.

Boone, S. A. (1986): Radiance from the Waters. New Haven: Yale University Press.

Cooper, W. (1971): Hair. Sex, Society, Symbolism. New York: Stein and Day.

Corson, R. (2005): Fashions in Hair. The First Five Thousand Years. London: Peter Owen.

Davidson, B. (1964): Černá paní. Praha: Mladá fronta.

Denny, F. M. (1998): Islám a muslimská obec. Praha: Prostor.

Derrett, J., \& Duncan M. (1973): Religious Hair. Man, 8 (1), 100-103.

Dolenský, A. et al. (1935): Dějiny účesu a ozdob k jeho hotovení uživaných I. a II. Praha.

Erman, A. (1971): Life in Ancient Egypt. New York: Dover.

Featherstone, M. (1999): Body Modification: An Introduction. Body \& Society, 5 (2/3), 1-13.

Firth, R. (1973): Symbols: Public and Private. London: Allen and Unwin.

Fisher, A. (1984): Africa Adorned. New York: Harry N. Abrams.

Fletcher, J. (2002): Ancient Egyptian Wigs \& Hairstyles. The Ostracon: Journal of the Egyptian Study Society, 13(2), 2-8.

Franbourg, A., Hallegot, P., \& Baltenneck, F. et al. (2003): Ethnic Hair \& Skin: What is the State of Science?, Supplement to Journal of the American Academy of Dermatology, 48 (6), 115-133.

Frazer, J. G. (1994): Zlatá ratolest. Praha: Mladá fronta.

Frazer, J. G. (2000): Zlatá ratolest - Druhá žeň. Praha: Garamond. 
Gennep van, A. (1997): Přechodové rituály - systematické studium rituáli̊. Praha: NLN.

Hallpike, C. R. (1969): Social Hair. Man, 9, 256-264.

Hérodotos (2004): Dějiny. Praha: Academia.

Heroldová-Štovíčková, V., \& Herold, E. (1994): Africké lásky, africká manželství. Praha: AZ Servis.

Hershman, P. (1974): Hair, Sex and Dirt. Man, 9, 274-298.

Hiltebeitel, A., \& Miller, B. D. (Eds.) (1998): Hair. Its Power and Meaning in Asian Cultures. New York: State University of New York Press.

Holub, E. (1952): Velké dobrodružství. Praha: Osvěta.

Holub, E. (1973): Cesta do země Mašukulumbů. Praha: Mladá fronta.

Jiroušková, J. \& Pecha, L. (2009): Africká sbírka. František Vladimír Foit. Praha: Národní muzeum.

Jiroušková, J., \& Dirnová, R. (2007): Dějiny odívání - Severní Afrika. Praha: NLN.

Jiroušková, J., \& Todorovová, J. (2003): Dějiny odívání - Černá Afrika, Praha: NLN.

Kandert, J. (1984): Afrika. Praha: Svoboda a Mladá fronta.

Klíma, V., \& Kubica, V. (1983): Safari za africkou kulturou. Praha: Práce.

Kropáček, L. (1998): Duchovní cesty islámu. Praha: Vyšehrad.

Kybalová, L. (1998): Dějiny odívání - Starověk. Praha: NLN.

Laude, J. (1973): Umění černého světadílu. Praha: Odeon.

Lawson, E. T. (1998): Náboženství Afriky. Tradice v proměnách. Praha: Prostor.

Leach, E. R. (1958): Magical Hair. The Journal of the Royal Anthropological Institute, 88, 147-164.

Lévi-Strauss, C. (1996): Myšlení př́rodních národi̊. Liberec: Dauphin.

Lévy-Bruhl, L. (1999): Myšlení člověka primitivního. Praha: Argo.

Lhote, H. (1962): Objevy v Tasíli. Praha: Mladá fronta.

Lhote, H. (1982): Jsou ještě jiná Tasíli. Praha: Mladá fronta.

Livingstone, D. (2006): A Popular Account of Dr. Livingstone's Expedition to the Zambesi and Its Tributaries. Middlesex: The Echo Library.

Malina, J. et al. (2007): Kruh prstenu 1. Světové dějiny sexuality. Brno: CERM/ Nauma.

Mattet, L. (Ed.) (2007): Arts of Africa and Oceania. Genève: Musée Barbier-Mueller.

McLeod, M. D. (1981): The Asante. London: British Museum Publications.

Meyerowitz, E. L. R. (1952): Shaving Off Hair as a Sign of Mourning. Man, $52(3), 47$.

Morris, D. (1971): Nahá opice. Praha: Mladá fronta.

Murdock, G. P. (1945): The Common Denominator of Culture. In Linton, R. (Ed.): The Science of Man in the World Crisis, 124-142. New York.

Neumann, S. K. (1999): Dějiny ženy. Praha: Otakar II. a Knižní klub.

Pauliny, J. (1990): Objevení Arábie. Praha: Panorama.

Pelikán, P. (1997): Sunna - pramen islámského práva. Praha: Právnická fakulta Univerzity Karlovy.

Polhemus, T. (Ed.) (1978): The Body Reader. Social Aspects of the Human Body. New York: Pantheon.

Pospíšil, L. (1993): Systémy víry: náboženství a magie. Český lid, 80, 388-412.

Post van der, L. (1967): Ztracený svět Kalahari. Praha: Mladá fronta.

Rantala, M. J. (2007): Evolution of nakedness in Homo sapiens. Journal of Zoology, 273, 1-7.

Rattray, R. S. (1927): Religion and Art in Ashanti. Oxford: Clarendon Press.

Rejchrtová, A. (2008): Vlasy jako text. K sémiotice kultury. Nepublikovaná diplomová práce. Praha: Filozofická fakulta Univerzity Karlovy.

Rubin, A. (Ed.) (1988): Marks of Civilization. Artistic Transformations of the Human Body. Los Angeles: UCLA Museum of Cultural History.

Rychlík, M. (2005): Tetování, skarifikace a jiné zdobení těla. Praha: NLN.

Rychlík, M. (2012): O jiném „uměni“ jiných: Vstup do antropologie umění. Culturologia, 1(1), 44-50.
Rychlík, M. (2013a): Účesy, vlasy, vousy a péče o ně. Praha (v tisku).

Rychlík, M. (2013b): Načesané lidstvo. S vlasy a vousy po celém světě. Vesmír, 92 (3), 150-155.

Sherrow, V. (2006): Encyclopedia of Hair: A Cultural History. Westport: Greenwood Press.

Sieber, R., \& Herreman, F. (Eds.) (2000): Hair in African Art and Culture. New York: Prestel.

Stanley, H. M. (1972): Jak jsem našel Livingstona. Praha: Orbis.

Stein, P. L., \& Rowe, B. (1993): Physical Anthropology. New York: McGraw-Hill.

Strouhal, E. (1989): Život starých Egyptanů. Praha: Panorama.

Synnott, A. (1987): Shame and Glory. A Sociology of Hair. The British Journal of Sociology, 38 (3), 381-413.

Šebesta, P., \& Lebzelter, V. (1933): Anthropologie středoafrických Pygmejů $v$ Belgickém Kongu. Praha: ČAV.

Šebesta, P., \& Lvová, S. (1956): Mezi nejmenšími lidmi světa. Praha: Mladá fronta.

Šedivý, E. (1921): Dějiny kosmetiky. Kulturní, medicinsko-historická studie. Praha: Březina.

Tiedemann, N. (2007): Haar-Kunst. Zur Geschichte und Bedeutung eines menschlichen Schmuckstücks. Köln: Böhlau Verlag.

Tomíček, J. S. (1846): Doba prwního člowěčenstwa aneb auplnějši wylíčení stawu prwního pokolení lidského. Praha: W komissí u Kronbergra a Řiwnáče.

Tylor, E. B. (1897): Úvod do studia člověka a civilizace (Anthropologie). Praha: Laichter.

Verner, M., Bareš, L., \& Vachala, B. (2007): Encyklopedie starověkého Egypta. Praha: Libri.

Vlach, J. (1911): Národopis všech světadíli̊. Praha: I. L. Kober.

Vlach, J. (1913): Žena ve zvycích a mravech národů. Praha: I. L. Kober.

Willcox, A. R. (1963): The Rock Art of South Africa. Johannesburg: Nelson.

Woodforde, J. (1971): The Strange Story of False Hair. London: Routledge.

\section{AUTOR}

Rychlík, Martin (11. 6. 1977, Broumov), český etnolog a novinář. Vystudoval etnologii i dějiny a teorii kultury na Filozofické fakultě Univerzity Karlovy v Praze s diplomovou a rigorózní prací na téma tetování $(2003,2004)$ a magisterskou prací o industriální hudbě EBM (2006). V roce 2011 dokončil doktorské studium v Ústavu etnologie (Dějiny tetování: Návrat archaismu a hnutí Modern Primitives). Doktorát zaměřený na „domorodé uměni“ dokončuje na Katedře kulturologie FF UK, kde přednáší antropologii umění a Polynésie. $\mathrm{V}$ roce 2009 absolvoval dvouměsíční stipendijní pobyt na University of Tokyo (komunikace vědy). V letech 2000-2006 pracoval jako redaktor v České tiskové kanceláři (ČTK), posléze v ekonomickém týdeníku Euro jako editor a reportér (2006-2010). Od roku 2010 je redaktorem portálu Česká pozice. Roku 2005 vydal v NLN knihu Tetování, skarifikace a jiné zdobení těla. K dějinám tatuáže uspořádal čtyři výstavy (Boskovice, Zlín, Jihlava, Praha).

Kontakt: PhDr. et Mgr. Martin Rychlík, Ph.D., Katedra teorie kultury (kulturologie), Filozofická fakulta Univerzity Karlovy, Celetná 20, Praha 1, 116 42; e-mail: martin.rychlik@ff.cuni.cz,rmt@email.cz 
